\title{
Stratigraphy and depositional environment of the Horton Group in the St. Marys Basin, central mainland Nova Scotia
}

\author{
J. Brendan Murphy and Randolph J. Rice \\ Department of Geology, St. Francis Xavier University, Antigonish, Nova Scotia B2G 2W5, Canada
}

\author{
Date Received January 31, 1997 \\ Date Accepted January 31, 1998
}

The St. Marys Basin, central mainland Nova Scotia, contains an Upper Devonian(?)-Lower Carboniferous intracontinental alluvial fan-fluviatile-lacustrine basin-fill sequence that occupies the current boundary between the Meguma and Avalon terranes of the Canadian Appalachian orogen. The basin rocks belong to the Horton Group, and are here divided into six partially laterally equivalent formations.

The stratigraphically lowest rocks are predominantly exposed in the central part of the basin in a series of en echelon anticlinal closures. These rocks were deposited in a longitudinal drainage system and represent clastic strata deposited in lacustrine (Little Stewiacke River Formation) and braided fluvial (Barrens Hills and Lochiel formations) environments.

Toward the southern flank of the basin the sequence is essentially a southeast-facing monocline in which the beds coarsen and thicken upward. Along this flank, clastic rocks were predominantly deposited in alluvial fans (Cross Brook and West River St. Marys formations) derived from the Meguma terrane to the south. These rocks unconformably overly the Meguma Group, reflecting a decrease in accommodation space and implying that the St. Marys Basin is underlain, at least in part, by Meguma basement.

In the northwestern part of the basin, clastic sedimentary rocks have mixed Avalonian-Meguma provenance (Graham Hill Formation) reflecting influence of the Avalonian margin to the north and confirming the status of the Horton Group as a post-Acadian overstep sequence.

The deposition of coarse conglomerate along the southern flank of the basin suggests a strong tectonic influence on sedimentation where subsidence along this basin margin occurred along northerly dipping listric normal faults. In contrast, the character of the sediments does not vary with proximity to the northern margin of the basin (Chedabucto Fault), suggesting that the fault does not constitute the original basin margin, and that an unknown portion of the basin and its Meguma basement have been tectonically removed.

Le bassin de St. Marys, dans le centre intérieur de la Nouvelle-Écosse, abrite une séquence de remplissage de bassin alluviale-fluviatile-lacustre continentale du Dévonien supérieur (?) au Carbonifère inférieur occupant la limite actuelle entre les terranes de Meguma et d'Avalon de l'orogène des Appalaches canadiennes. Les roches du bassin font partie du groupe de Horton et elles se divisent en cet endroit en six formations partiellement équivalentes latéralement.

Les roches les plus basses du point de vue stratigraphique affleurent principalement dans la partie centrale du bassin sous forme d'une série de fermetures d'anticlinaux en échelons. Ces roches se sont déposées le long d'un réseau hydrographique longitudinal et elles se manifestent par des strates clastiques s'étant déposées dans des milieux lacustres (Formation de Little Stewiacke River) et fluviaux anastomosés (formations de Barrens Hills et de Lochiel).

Vers le flanc méridional du bassin, la séquence constitue essentiellement une structure monoclinale orientée vers le sud-est dans laquelle les strates deviennent plus grossières et s'épaississent en allant vers le haut. Le long de ce flanc, les roches clastiques se sont surtout déposées en cônes alluviaux (formations de Cross Brook et de West River St. Marys) provenant du terrane de Meguma, au sud. Ces roches recouvrent de façon discordante le groupe de Meguma, ce qui est révélateur d'une diminution de l'espace disponible et laisse supposer que le bassin St. Marys repose, du moins en partie, sur le socle de Meguma.

Dans le nord-ouest du bassin, les roches sédimentaires clastiques proviennent à la fois des terranes d'Avalon et de Meguma (Formation de Graham Hill). Cette origine mixte témoigne de l'influence de la marge d'Avalon au nord et elle confirme que le groupe de Horton constitue une séquence discordante ultérieure à l'Acadien.

L'accumulation de conglomérat grossier le long du flanc méridional du bassin laisse supposer une forte influence tectonique sur la sédimentation dans le secteur où est survenu un affaissement le long de la limite du bassin longeant des failles normales courbes, inclinées vers le nord. Par contraste, le caractère des sédiments ne varie pas en fonction de la proximité avec la limite nord du bassin (faille de Chedabucto), ce qui semble indiquer que la faille ne constitue pas la limite d'origine du bassin et qu'une partie inconnue du bassin et du socle de Meguma correspondant en ont été tectoniquement écartés.

[Traduit par la rédaction] 


\section{INTRODUCTION}

The St. Marys Basin of central mainland Nova Scotia is located on the southern flank of a Late Paleozoic composite basin, variously known as the Maritimes or Magdalen Basin, in the Canadian Appalachian orogen (Fig. 1). This larger basin comprises several intra-continental depocentres dominated by clastic rocks of Late Devonian-Permian age (Bradley, 1982). These rocks are generally interpreted to have been deposited in a late- to post-orogenic continental regime formed after the destruction of the Iapetus Ocean either during waning stages of the Acadian orogeny (e.g., Keppie, 1982a,b) or as postAcadian successor basins (e.g., Williams, 1978, 1979). However, mechanisms of basin formation and evolution are controversial.

The St. Marys Basin averages $15 \mathrm{~km}$ in width and extends for about $130 \mathrm{~km}$ from Chedabucto Bay in the east to the Bay of Fundy in the west. Basin-fill sedimentary rocks have been traditionally assigned to the Upper Devonian-Lower Carboniferous Horton Group (e.g., Benson, 1967, 1974). The basin occupies the present boundary between Avalonia (also known as the Avalon Composite Terrane) of northern mainland Nova Scotia, dominated by Late Precambian volcanic and sedimentary rocks, and the Meguma terrane of southern mainland Nova Scotia, dominated by Cambrian and Ordovician metasedimentary rocks intruded by Devonian granitoid plutons. Basin-fill rocks were deformed in Late Carboniferous time (Namurian-Westphalian) by folds and faults related to regional dextral strike-slip motion along major faults, including the Chedabucto Fault, which is a major fault along the Avalon-Meguma terrane boundary (Murphy et al., 1995).

The Horton Group is traditionally regarded as a sequence that oversteps terrane boundaries in the northeastern Appalachian orogen (e.g., Keppie, 1985). As such, stratigraphic correlations have been proposed between Horton Group sequences in geographically separate subbasins of the Maritimes Basin (e.g., Martel and Gibling, 1996). However, many authors have noted that clasts in the Horton Group are predominantly of local derivation (e.g., Hamblin and Rust, 1989; Murphy et al., 1994), implying that regional correlations may not be as straightforward as is generally assumed.

The St. Marys Basin in central mainland Nova Scotia is situated between the type area of the Horton Group in the Annapolis Valley near Windsor and various sections in Cape Breton Island (e.g., Martel and Gibling, 1996). Accordingly, the basin is strategically positioned to evaluate the merit of these regional correlations. In this paper, we define and describe the stratigraphic units of the basin, interpret their depositional environments, and briefly evaluate their regional significance.

\section{Previous work}

Fletcher and Faribault (1887) prepared the first geological maps of the area as part of a regional survey of northeastern mainland Nova Scotia. Benson $(1967,1974)$ mapped the majority of the basin (parts of map sheets $11 \mathrm{E} / 07$ and $11 \mathrm{E} / 08$ ) at scales of 1:63,360 and 1:50,000, respectively. He assigned all basin-fill sedimentary rocks to the Horton Group which he considered to be Early Carboniferous (Tournaisian) in age on the basis of paleontological evidence. He further divided the group into the Craignish, Strathlorne, and Ainslie formations (in ascending order) on the basis of lithological and stratigraphic similarities with the type areas of these formations in Cape Breton Island as described by Murray (1960) and Kelley (1967). According to Benson (1974), the St. Marys Basin developed as a post-orogenic graben as a result of left-lateral strike-slip and minor dip-slip movements on the Chedabucto Fault.

Schiller $(1961,1963)$ mapped the eastern portion of the basin (parts of map sheets $11 \mathrm{~F} / 05$ and $11 \mathrm{~F} / 04$ ) at a one-inch to one mile scale $(1: 63,360)$, as part of a study of the geology of Guysborough County. Mooney (1990) and Hill (1991) also mapped the easternmost portion of the basin as part of their regional studies. The latter two authors assigned the rocks within this portion of the basin to the Gunns Brook Formation, which they interpreted to be broadly correlative with part of the Horton Group.

The westernmost portion of the basin (mapsheet $11 \mathrm{E} / 06$ ) was mapped and regional fold patterns identified by Stevenson (1956, 1958), who assigned St. Marys Basin rocks to either the Horton Group, or the Late Carboniferous Canso Group (now known as the Mabou Group) and identified regional fold patterns.

\section{STRATIGRAPHIC NOMENCLATURE}

A summary of the regional geology of the St. Marys Basin is shown in Figure 2a. As a result of the present study, six new formations are defined, as described below. In general, the contacts between formations are conformable and gradational, with interlayering of characteristic lithologies adjacent to contacts. This observation, together with paleontological data (Benson, 1974; G. Dolby, personal communication, 1994), suggests that the units are broadly coeval, and may be in large part facies equivalents. With the important exception of the northwestern portion of the basin, lithologies are notable for the presence of clasts characteristic of the Meguma terrane to the south. Formations in the northwestern part of the basin contain the first documentation of a mixed AvalonianMeguma provenance within the Horton Group.

In general, regional facing is profoundly influenced by a regional northeast-trending anticline in the Stewiacke River region in the central portion of the basin (Fig. 2a). The oldest rocks, the Little Stewiacke River Formation occur in the core of this structure with progessively younger rocks to the northwest and southeast. This regional northeast-trend predominates in the eastern part of the basin with the exception of local reversals near the hinges of a few minor folds. Facing directions in the western part of the basin are profoundly influenced by regional folds (Fig. 3).

The six new formations are justified because the sequence shows significant differences compared to the Horton Group in both the type area near Windsor (Martel and Gibling, 1996) in the Annapolis Valley to the west, and in Cape Breton Island to the northeast. Although Benson $(1967,1974)$ used the 


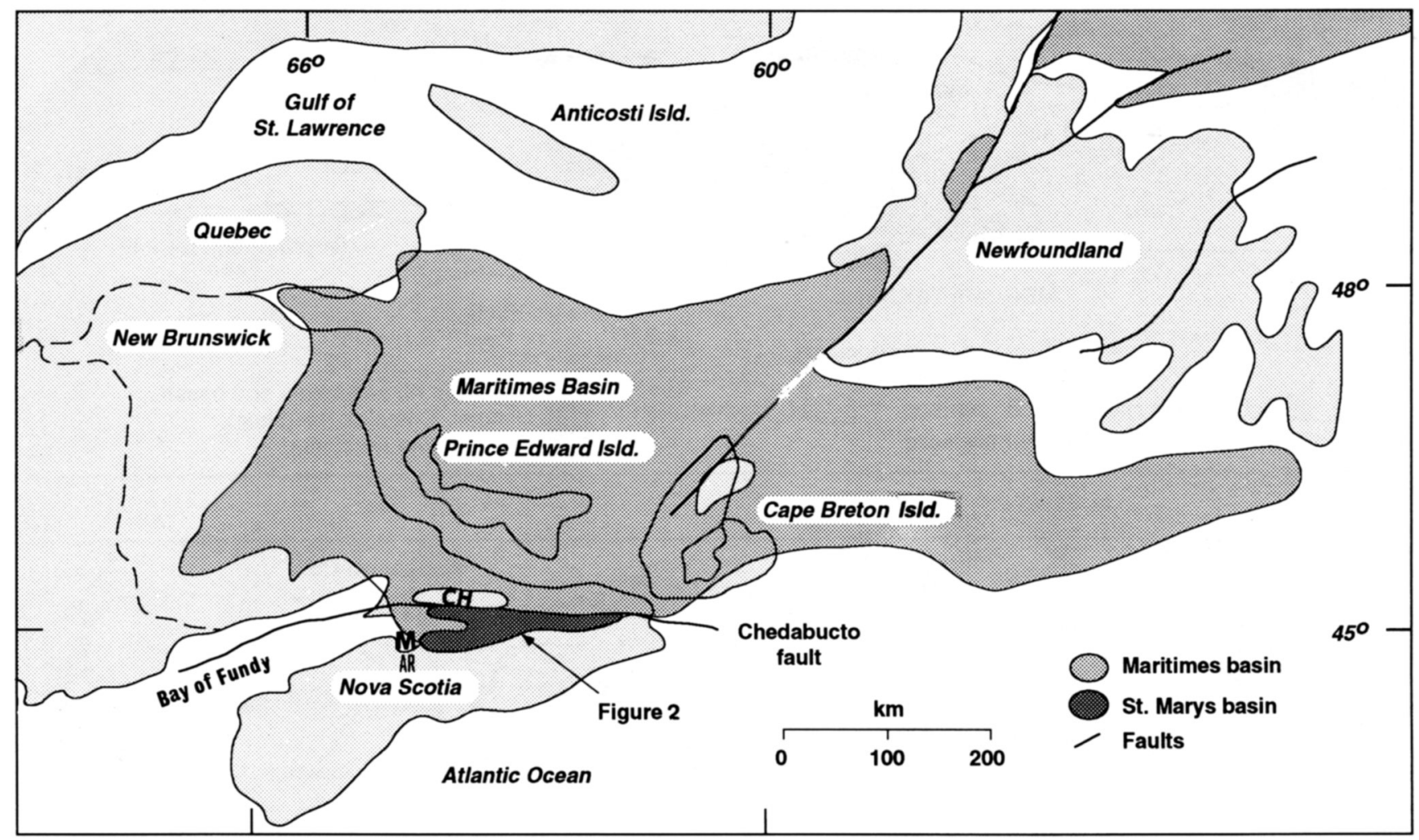

Fig. 1. Location of the St. Marys Basin along the southern flank of the composite Maritimes Basin (after Williams, 1978; Martel, 1987). $\mathrm{CH}=$ Cobequid Highlands, $\mathrm{M}=$ Minas Basin, $\mathrm{AR}=$ Avon River type section for the Horton Group.

stratigraphic nomenclature of the Horton Group in Cape Breton Island as previously defined by Murray (1960), this usage appears inappropriate as a result of the present work. As outlined below, the study area is dominated by clastic rocks predominantly derived from the Meguma terrane. Given the relatively local derivation of these clasts, correlation with the Horton Group in Cape Breton Island gives a misleading impression of stratigraphic and tectonic simplicity. Although it is possible that the formations in the St. Marys Basin may correlate with those in Cape Breton Island, Cape Breton Island stratigraphy is not directly applicable to the basin.

In the western portion of the basin (Fig. 3) mapping and palynological evidence indicate that the rocks assigned by Stevenson (1958) to the Canso Group should be re-assigned the Horton Group. Our map (Fig. 2a) differs from that of Donohoe and Wallace (1982) in that the Horton Group strata are subdivided. In the central and eastern portions of the basin, Benson $(1967,1974)$ interpreted rocks assigned here to the Barrens Hills Formation as the oldest rocks in the region, with younger formations to the north and south. In contrast, on the basis of numerous facing determinations in the vicinity of the northern contact, we interpret the Barrens Hills Formation to overlie the Little Stewiacke River Formation and to be part of an essentially monoclinal southeasterly facing succession that extends to the southern flank of the basin (Fig. 3).

\section{Little Stewiacke River Formation}

\section{Definition and lithologic description}

The Little Stewiacke River Formation consists of interstratified, thinly bedded, bioturbated mudstone, fissile, light to dark grey and black shale and slate, and light to dark grey sandstone commonly containing abundant comminuted plant debris. Coarsening-and thickening-upward cycles, 2 to $25 \mathrm{~m}$ thick, contain individual beds ranging in thickness from $2 \mathrm{~mm}$ to $15 \mathrm{~cm}$ (Fig. 4a). In some localities the sandstones display soft-sediment deformation (Fig. 4b). In many sections, the finer-grained lithologies display a slaty cleavage (Fig. 4c).

The formation is named after Little Stewiacke River (Fig. 2b), a tributary of the Stewiacke River, which contains all the diagnostic lithologies. In some parts of the map area, notably in the vicinity of the Stewiacke River (see Fig. 3), the formation can be subdivided into lower and upper members depending on the relative abundance of interstratified shale and sandstone. Where the formation cannot be subdivided, it generally contains aspects of both members. The upper member is distinguished by having a greater proportion of sandstone (> $35 \%$, Fig. 4d). 

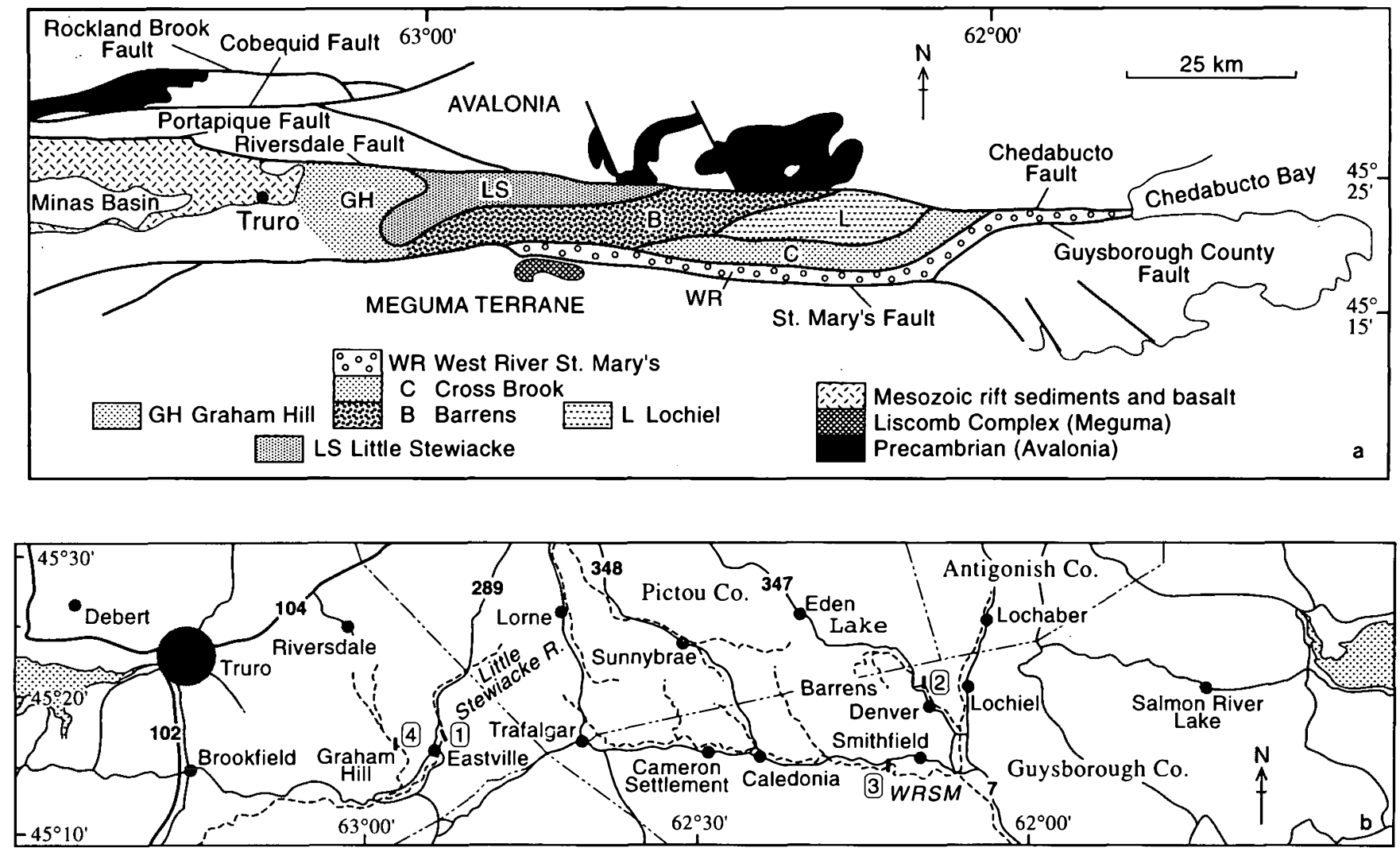

Fig. 2. (a) Summary geological map of the St. Marys Basin showing distribution of formations of the Horton Group. Little Stewiacke River, LS, map unit 1 of Murphy et al., 1995; Barrens Hills, B, map unit 2a; Lochiel, L, map unit 2b; Cross Brook, C, map unit 3; West River St. Marys, WR, map unit 4; Graham Hill, GH, map unit 5. For location, see Figure 1. (b) Geographic location of St. Marys Basin in mainland Nova Scotia showing the place names mentioned in the text and the main highways (numbered). WRSM = West River St. Marys. The location of measured sections (numbered 1 to 4 ) are shown (see Figs. 5 and 7 for details). Section 1 is the location of the section across the contact between the Little Stewiacke River and Barrens Hills formations (see Fig. 5). The locations of sections 2,3 and 4 are in the Lochiel, West River St. Marys and Graham Hill formations, respectively (see Fig. 7).

In the lower member, interstratification of silty shale/shaly siltstone and sandstone is on a scale of millimeters to decimeters. These rocks contain abundant thin quartz veins oblique to bedding, indicative of heterogeneous strain associated with deformation. Siltstone/shale-sandstone contacts are either sharp or transitional, or, less commonly, erosional. Sandstones are typically grey- or dark grey-weathering, very fine- to finegrained and micaceous, and in some locations, moderately feldspathic. Primary and penecontemporaneous sedimentary features include normal grading, parallel lamination, ripple cross-lamination, loading features, and bioturbation. Sandstone strata generally vary from millimeters to decimeters in thickness. The dark weathering colour of the sandstone, siltstone, and shale in this member is due to the common presence of comminuted plant debris. Siltstone and shale are better laminated, dark grey- to black-weathering, micaceous and can also contain bioturbated intervals. Excellent roadcut exposures of the lower member on the Lorne-Trafalgar road (Fig. 2b) contain coarsening- and possibly thickening-upward cycles of shale-siltstone-sandstone on the order of several meters to several tens of meters in thickness.

In general, the upper member consists of shale and siltstone similar to those of the lower member. Locally, these lithologies contain disseminated and nodular pyrite. Bedding is commonly discontinuous and can be locally transposed along cleavage planes. However, the interbedded coarser sandstones and conglomerates are uncleaved. The amount of interstratified sandstone increases up section. The sandstone occurs in coarsening- and thickening-upward cycles up to tens of metres in thickness (Fig. 5). The coarser portions of these cycles consist of repetitive thin (tens of centimetres) coarsening-upward cycles. The coarse clastic rocks consist of sandstone with abundant granulestone layers and minor small quartz-pebble conglomerate beds and lenses up to several centimeters in thickness. In general, the sandstone weathers grey to dark grey and is very fine- to medium-grained, micaceous and feldspathic. Sandstone units are approximately one meter thick and, as in the lower member, display parallel lamination, ripple cross-lamination, normal grading, and crossbedding (dominantly trough). Erosional basal contacts are common.

As the contact with the overlying Barrens Hills Formation is approached, the upper member lithologies are coarser and erosionally amalgamated with channel scours and possible swaley cross-stratification, and display large scale (10$20 \mathrm{~cm}$ ) trough cross-stratification. Fine organic debris is typically abundant and the weathering colour darkens accordingly. 


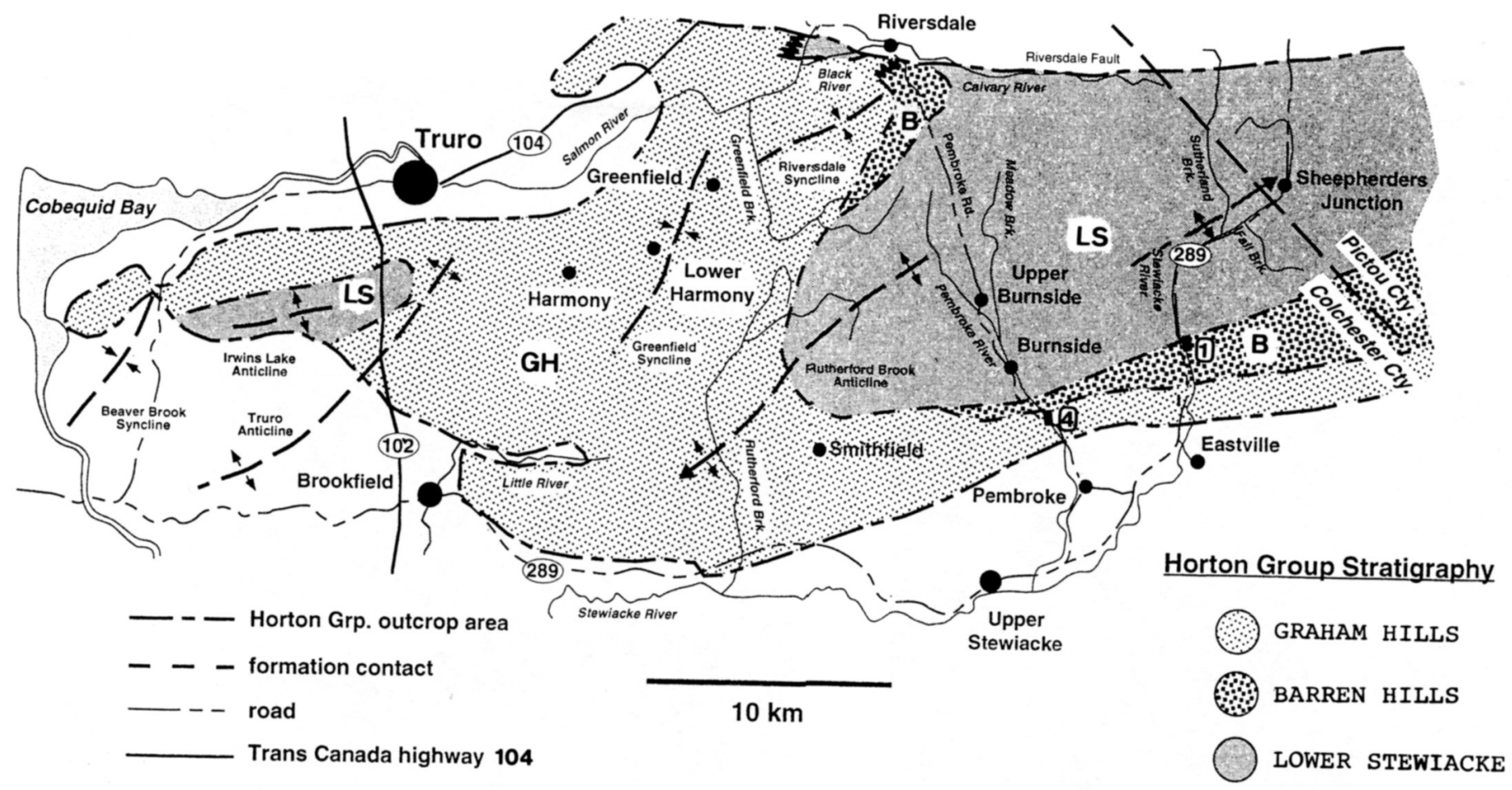

Fig. 3. Summary geological map of the western St. Marys Basin showing distribution of formations (LS, Little Stewiacke River; GH, Graham Hill; B, Barrens Hills) and fold hinge surface traces. Note the opposing plunges of the folds in the Stewiacke River and Rutherford Brook areas. The location of measured sections (Figs. 5, 7) in the Little Stewiacke River and Barrens Hills formations (1) and Graham Hill Formation (4) are shown.

\section{Stratigraphic position}

Our mapping indicates that the Little Stewiacke River Formation is the oldest formation in the St. Marys Basin (the formation was informally referred to as unit 1 in Murphy et al., 1994, 1995). The base of the formation is not exposed. The upper contact (with the Barrens Hills Formation) is defined where very distinctive resistant beds of pale grey to white sandstone become dominant. Facing criteria (see above) near the contact clearly demonstrate that the Little Stewiacke River Formation lies beneath the Barrens Hills Formation.

\section{Distribution, thickness and contact relationships}

The Little Stewiacke River Formation is well exposed in the Stewiacke River region along provincial Highway 289, and along adjacent streams including Little Stewiacke River (Fig. 2a, b). It can be mapped for more than $60 \mathrm{~km}$ along strike from Rutherford Brook in the west (Fig. 3) to Eden Lake in the east where it is truncated by the Chedabucto Fault (Fig. 2a). As the base of the formation is not exposed, only a minimum thickness can be calculated. In addition, thickness estimates are further complicated by the presence of open, shallowly plunging northeasterly trending folds with wavelengths of several hundred metres, as indicated by cleavage-bedding relationships and facing reversals. However, we agree with Benson $(1967,1974)$ who estimated that the formation (mapped by him as the Strathlorne Formation) is at least 800 to $950 \mathrm{~m}$ in thickness.
The contact between the lower and upper members is transitional over $10 \mathrm{~m}$ and is exposed on the Stewiacke River about $750 \mathrm{~m}$ north of the bridge on Highway 289 (Fig. 3). The contact with the overlying Barrens Hills Formation is also exposed on the Stewiacke River about $200 \mathrm{~m}$ south of the bridge. Benson (1974) positioned this contact about $300 \mathrm{~m}$ north of the bridge in a structurally complex section. We speculate that this may have contributed to what we believe is an erroneous interpretation of facing and the stratigraphic order of the Barrens Hills and Little Stewiacke River formations in the vicinity of this contact.

Lithologic contrasts across the contact (from the dark, fissile, fine-grained, thinly bedded lithologies of the Little Stewiacke River Formation to the light coloured resistant, coarse, amalgamated sandstone-dominated lithologies of the Barrens Hills Formation) are very distinctive, facilitating relatively precise location (on a 1:50,000 scale map) in areas of reasonable outcrop.

West of Truro, the formation is exposed to the west of Highway 102 in the core of an easterly plunging anticline (Fig. 3) where it is overlain by the Graham Hill Formation, which is, in part, a lateral facies equivalent of the Barrens Hills Formation (see below). Contacts between the Graham Hill and Barrens Hills formations are only approximately defined. However, to the northeast of Truro, near Riversdale (Figs. 2b, 3), the Little Stewiacke River lithologies are interstatified with lithologies typical of both the Barrens Hills and Graham Hill formations. This relationship indicates a partial facies equivalence among the formations. 

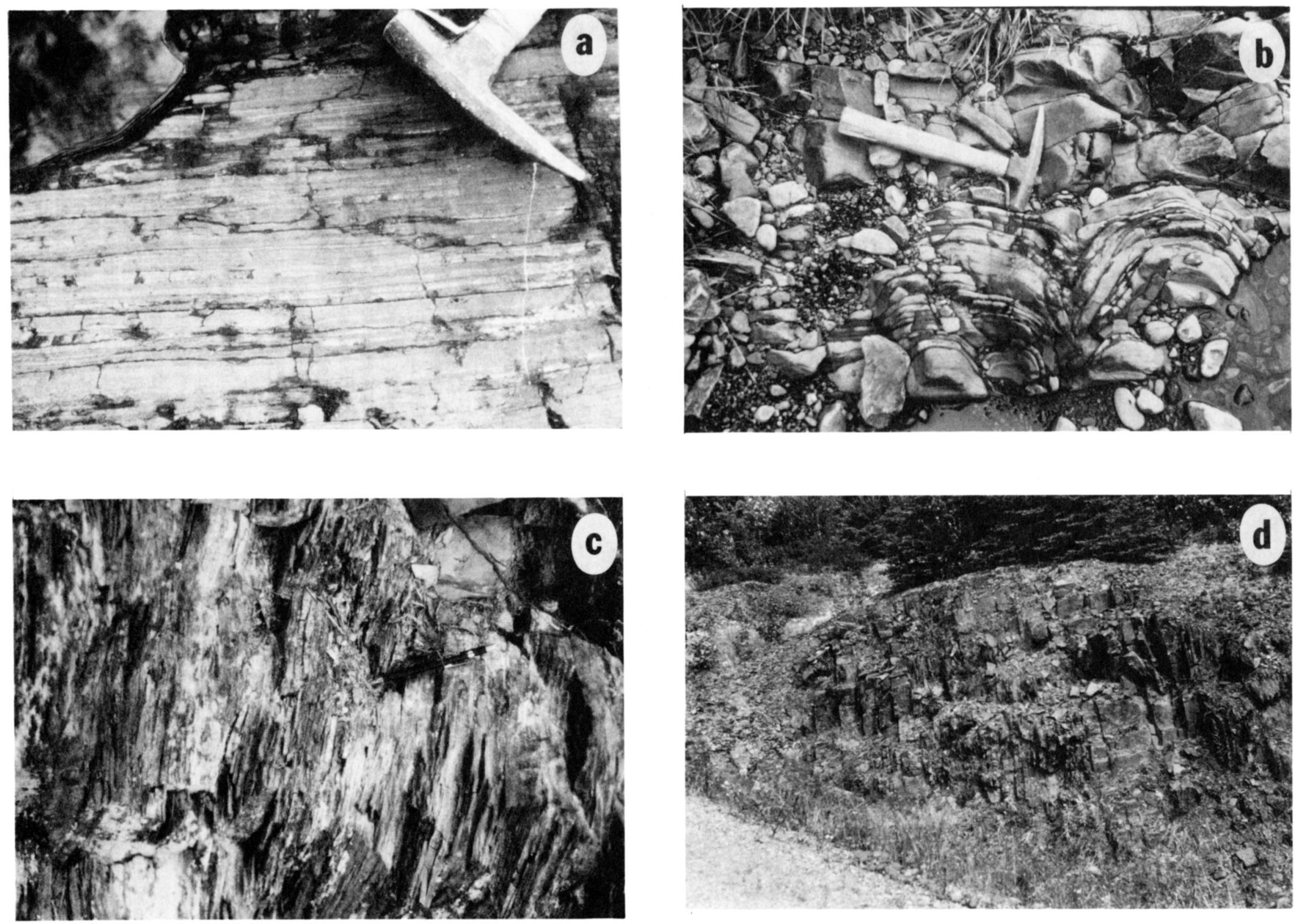

Fig. 4. Field photographs of the Little Stewiacke River Formation. (a) Interstratified, parallel-laminated to very thin-bedded, black siltstone and grey siltstone with local ripples in lower member, Stewiacke River north of Eastville. (b) Marginal lacustrine, interstratified siltstone and very fine sandstone with soft sediment deformation possibly indicating synsedimentary seismic disturbance. Upper member, on Stewiacke River north of Eastville. (c) Lacustrine, intercalated, black, very fine sandstone and grey siltstone. $S_{1}$ cleavage is at a low angle to bedding in this outcrop. Lower member, Stewiacke River. (d) Marginal lacustrine, sandstone dominant sequence of interstratified grey, very fine sandstone and black siltstone. Upper member, Stewiacke Road north of Eastville. 

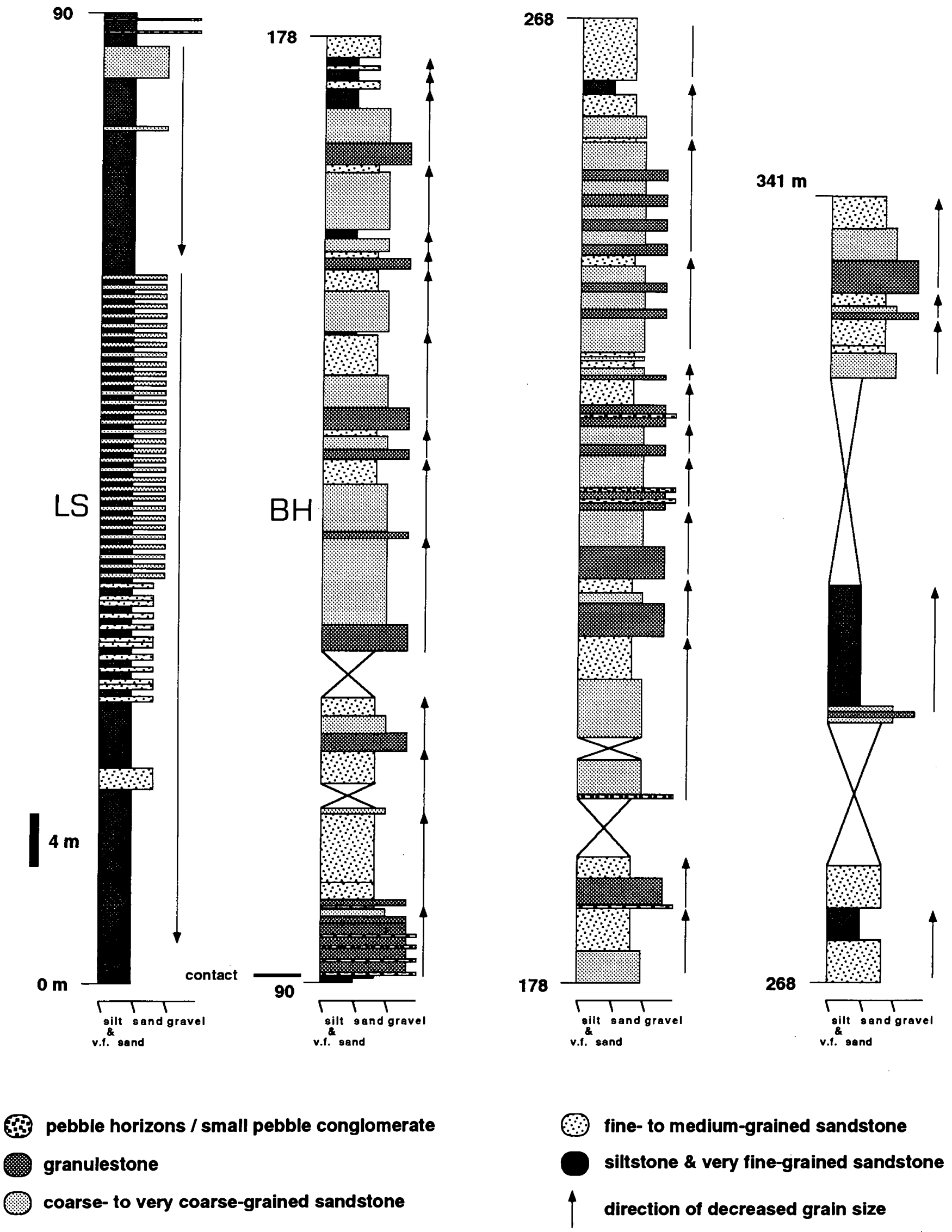

Fig. 5. Measured section of the Little Stewiacke River (LS) and Barrens Hills (BH) formations in the Stewiacke River southeast of Highway 289. 
The Little Stewiacke River Formation is bounded to the north by the Riversdale and Chedabucto faults. The orientation of the beds rotate clockwise and steepen within $2 \mathrm{~km}$ of the fault. Locally, outcrop-scale folding and faulting, attributed to motion along the fault are common.

\section{Age}

Twenty-one samples were analyzed for spore assemblages (Graham Dolby, written communication, 1995). The assemblages indicate a Tournaisian age, findings consistent with those reported in Benson (1974). However, a more definitive determination was not obtained as assemblages were too oxidized for precise identification. This feature is common in similar rocks of the Horton Group in the Annapolis Valley and Cape Breton Island (e.g., Utting and Hamblin, 1991).

\section{Barrens Hills Formation}

\section{Definition and lithologic description}

The Barrens Hills Formation is characterized by resistant intervals of light grey- to grey-white-weathering, fine- to very coarse-grained sandstone (Fig. 6a) and monomict or polymict granulestone and conglomerate (Fig. 6b), interstratified with recessive intervals of micaceous grey- to dark grey-weathering shale and/or siltstone (Fig. 6c). Interbeds of relatively minor red siltstone and sandstone also occur, as previously described by Benson (1974). The formation is named after the "Barrens Hills" region of the eastern St. Marys Basin, so named because of sparse tree cover.

Near the basal contact with the Little Stewiacke River Formation, coarse pebbly (quartz) sandstone, quartz granulestone, and, less commonly quartz-pebble conglomerate layers (10$30 \mathrm{~cm}$ thick) occur at the base of fining-upward sequences (Figs. 5, 6b,d). The pebbly sandstone and granulestone also occur higher up in the stratigraphy in isolated outcrops along the Stewiacke and Pembroke rivers (Fig. 3). The sandstone is grey to off-white and is very fine- to very coarse-grained, and poorly to moderately sorted. Variably well-defined fining-upward cycles range from 2 to $10 \mathrm{~m}$ thick (Fig. 5). Ripple crosslamination and trough cross-stratification $(4-20 \mathrm{~cm})$ are common. Organic debris occurs locally.

The sandstone is dominated by quartz and feldspar and lacks the plentiful grey sedimentary lithic clasts present in the Barrens Hills lithologies near the base of the formation. Feldspars are generally intensely weathered to clay minerals. Locally, the sandstone is slightly micaceous and moderately feldspathic, and contains varying but significant amounts of dark grey sedimentary lithic clasts of schist and sandstone, some with a fabric, that were probably derived from the Meguma terrane south of the St. Marys Basin. Near Riversdale (Figs. $2 \mathrm{~b}, 3$ ), the sandstone typically contains minor but distinctive subangular to subrounded clasts of felsic volcanic rocks. Coarsergrained sandstones commonly contain steeply dipping en echelon quartz veins that strike northwest to north-northwest, i.e., at high angles to bedding. Conglomerate is similar to sandstone and is characterized by distinctive quartz pebbles and a variety of metasedimentary lithic clasts. Micaceous siltstone shows parallel lamination and ripple cross-lamination.

\section{Stratigraphic position}

In Murphy et al. (1994, 1995), the formation was referred to informally as map unit 2a. Benson $(1967,1974)$ mapped this unit as the Craignish Formation (based upon correlations with sections in Cape Breton Island) and considered the sandstone to be stratigraphically equivalent to those of the Horton Bluff Formation in the Avon River type area. However, as discussed above, the stratigraphic placement of these rocks below the Little Stewiacke River Formation contradicts stratigraphic facing evidence. Therefore, the unit cannot be correlated with the Craignish Formation, as implied by Benson $(1967,1974)$. Instead, as described above, the Barrens Hills Formation conformably overlies the Little Stewiacke River Formation.

In addition, Benson $(1967,1974)$ made a regional observation that his Craignish Formation fines both southward toward the Meguma terrane and stratigraphically upward where minor reddish-grey sandstone and mudstone occur. In the revised stratigraphy presented here, these trends are not supportable.

\section{Distribution, thickness and contact relationships}

The Barrens Hills Formation underlies large areas of both the central and eastern St. Marys Basin where it outcrops along a broad, regional, northeast-trending anticlinal axis (Fig. 2a). It thins dramatically to the west of the Stewiacke River region toward Truro, and the formation underlies only a small portion of this region where it wraps around a synclinal axis south of Riversdale (Fig. 3) and passes into the laterally equivalent Graham Hill Formation. To the east, in the eastern portion of the Lochaber mapsheet, it passes into the laterally equivalent Lochiel Formation (Fig. 12).

The basal contact is positioned where sand- to granulesize quartz-rich clastic sediment starts to predominate over darker and more thinly bedded lithologies of the Little Stewiacke River Formation. This contact is shown on the measured section in the Stewiacke region (Fig. 5) where it is transitional over $1 \mathrm{~m}$. It is recognized by the abrupt occurrence of thin $(10-20 \mathrm{~cm})$ lenses of small pebble conglomerate at the base of the Barrens Hills Formation.

The upper contact occurs farther east where the formation is conformably overlain by the Cross Brook Formation (Fig. 3). The contact between these formations is gradational over $100 \mathrm{~m}$ and is defined where the green feldspathic sandstone, siltstone, and shale of the Cross Brook Formation predominate. To the north, near Eden Lake (Fig. 2b), the Barrens Hills Formation is truncated by the Chedabucto Fault (Fig. 3).

Excellent exposures in several regions afford opportunities to characterize and study facies and thickness variations within the formation. Thickness estimates of $1000 \mathrm{~m}$ and 1600 $\mathrm{m}$ are derived from exposures on the Pembroke and Stewiacke rivers, respectively (Fig. 3). The thickness estimate along the 

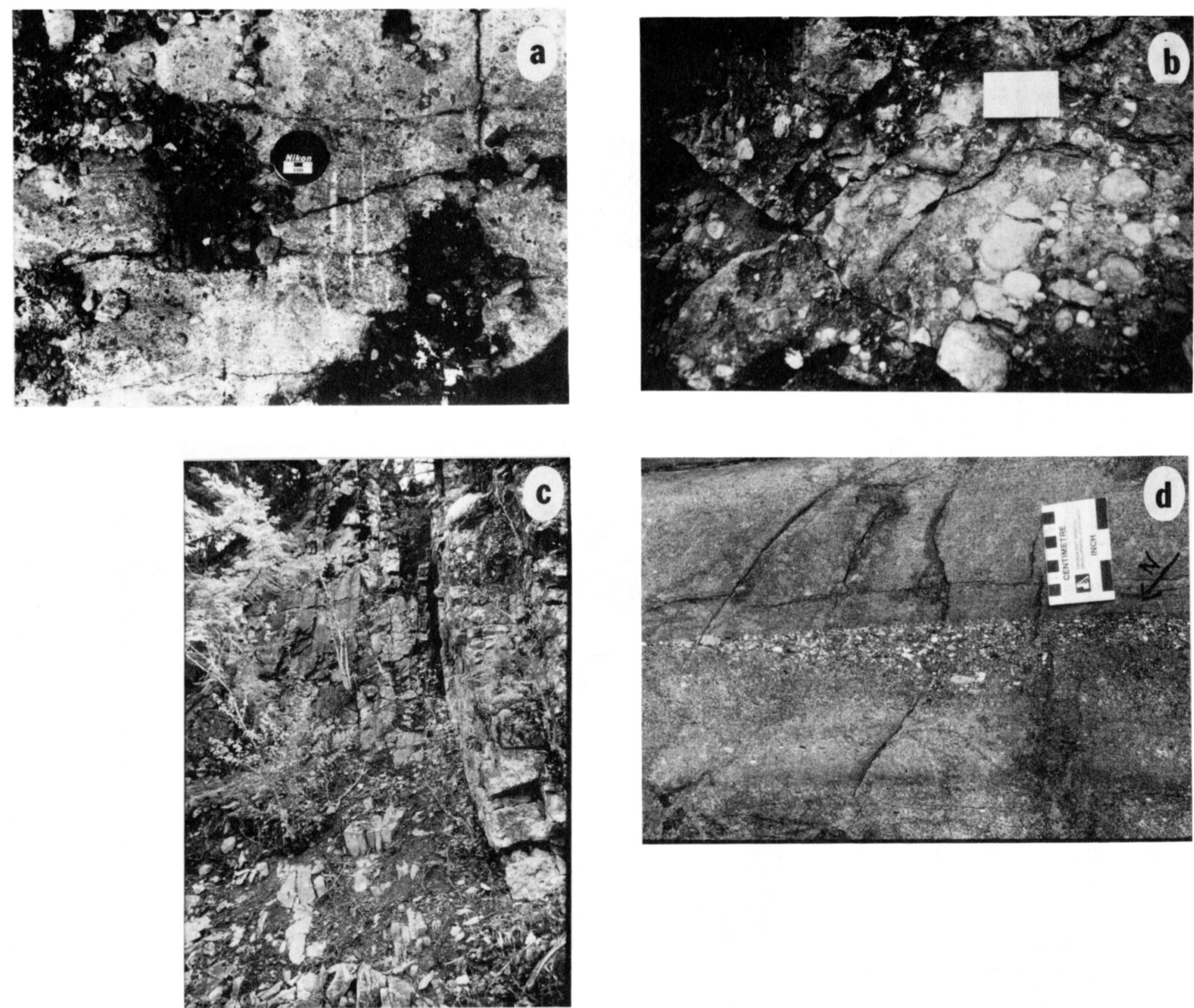

Fig. 6. Field photographs of lithologies of the Barrens Hills Formation. (a) Quartz granule to small pebble conglomerate with dark grey sedimentary rock fragments, and en echelon quartz veins, Stewiacke River north of Eastville. (b) Basal polymictic quartz pebble conglomerate bed in a fining-upward sequence, section 1 on Figure 2a, Stewiacke River north of Eastville (see Fig. 4). (c) Basal channel sandstone (right) in erosional contact with recessive finer-grained sandstones and siltstones of an underlying fining-upward sequence, section 1 on Figure 2a, Stewiacke River north of East ville. (d) Graded, granule to small pebble conglomerate stratum, Stewiacke River, north of section 1. 
Stewiacke River is derived from an approximately monoclinal, southward-facing section east of Highway 289 . This thickness exceeds the ca. $600 \mathrm{~m}$ estimate of Benson (1967) for the same region which he based on "many small sections whose relations to each other are commonly in doubt".

\section{Age}

Despite extensive sampling, no datable fossil material was recovered from the Barrens Hills Formation in this study. Benson $(1974$, p. 53) found large plant fragments (Lepidodendropsis) in sandstone and spores in shale and siltstone in what he considered to be the Craignish Formation (here assigned to the Barrens Hills Formation). These samples correlate with the Late Devonian-Tournaisian Horton Bluff Formation in the Avon River type area (see Martel and Gibling, 1996) suggesting that deposition of the Barrens Hills Formation and the Horton Bluff Formation may have overlapped temporally.

\section{Lochiel Formation \\ Definition and description}

The Lochiel Formation is named after exposures in the vicinity of Lochiel Lake (formerly known as Two Mile Lake) to the south of Lochaber Lake. The type section is selected on the East River St. Marys near Denver (Fig. 2b).

The Lochiel Formation typically consists of sandstone which is grey or green, fine- to very coarse-grained, micaceous and feldspathic, interbedded with minor granulestone and dark grey siltstone. A stratigraphic section (Fig. 7a) was measured in the upper part of the formation at Gunhole (location 2, Fig. 2b) and represents the type section. The sandstone locally contains isolated quartz granules. Coarse conglomerate was not observed. The formation is distinguished from the Barrens Hills Formation to the west by the paucity of resistant mature light grey- to grey-white quartz-feldspar sandstone and conglomerate.

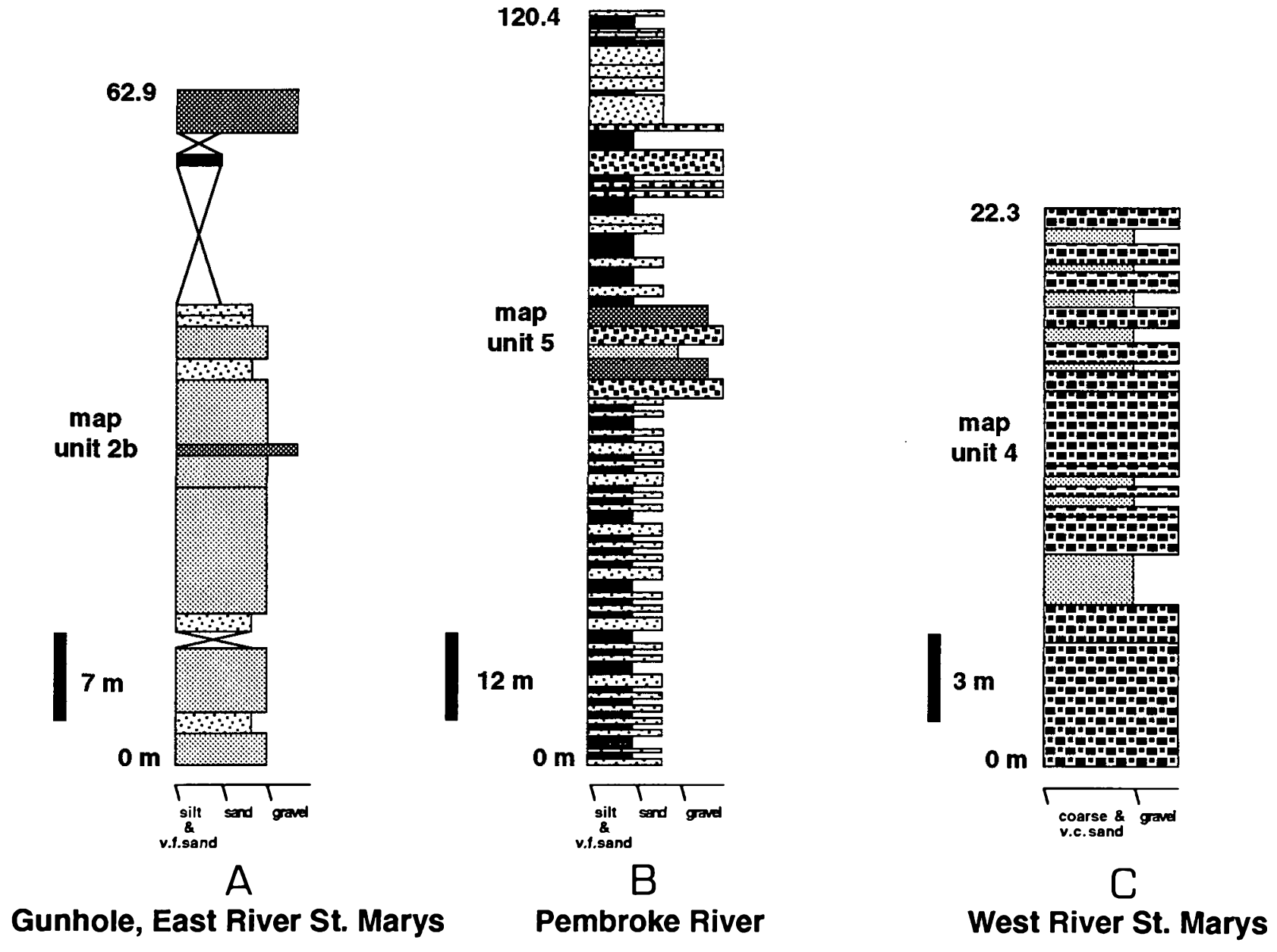

\author{
coarse- to very coarse-grained sandstone \\ fine- to medium-grained sandstone \\ siltstone to very fine grained sandstone
}

Fig. 7. Measured sections showing characteristics of (A) Lochiel Formation, near Gunns Hole on the East River St. Marys, (B) the Graham Hill Formation measured on the Pembroke River, and (C) the West River St. Marys Formation. Locations are given in Figure 2a. 
Sandstone beds range from $5 \mathrm{~cm}$ up to $2 \mathrm{~m}$ in thickness. The measured section (Fig. 7a) suggests the presence of fining-upward cycles with bases defined by granulestone beds. Sandstone beds occur in measured intervals up to $17 \mathrm{~m}$ in thickness. Parallel lamination, ripple cross-lamination, and largescale cross-bedding are common in the sandstone. The crossbeds are both trough (dominant) and planar with set thicknesses varying from 0.1 to $0.6 \mathrm{~m}$. Cosets of trough crossstratification are up to several meters thick. Grey-weathering siltstone similar to that in the Barrens Hills Formation is sparse in the Gunns Hole section and occurs in recessive, highly fractured intervals 1 to $2 \mathrm{~m}$ thick. Parallel lamination and ripple cross-lamination are present in the siltstone but may be partially masked by fracturing.

The resistant sandstone units contain quartz veins and are fractured with slickensides indicating proximity to the Chedabucto Fault. They also display outcrop-scale flexures indicating the presence of open folds.

\section{Stratigraphic position}

Benson (1974) mapped much of this region as the Ainslie Formation, based on correlations with successions in Cape Breton Island, which he correlated with the Cheverie Formation of the type area in the Annapolis Valley. In the present study, the formation is considered to be largely a lateral facies equivalent of the Barrens Hills Formation (see Murphy et al., 1994). This interpretation is based on the observation that both formations are conformably (and transitionally) overlain by the Cross Brook Formation (described below), and on the fact that minor resistant quartzo-feldspathic sandstones, typical of the Barrens Hills Formation, occur in the western part of the Lochiel Formation. Exposure is limited to the west of the East River St. Marys, and our assignment of rocks in the Mitchell-Indian Man lakes region to this formation is tentative.

\section{Distribution, thickness and contact relations}

The best exposures of the Lochiel Formation occur principally in the type area. Based on these exposures, Murphy et al. (1994) proposed a minimum thickness of $500 \mathrm{~m}$. To the northeast of the type area, the formation is truncated by the Chedabucto Fault. The contact between the Lochiel and Barrens Hills formations is not exposed. Although the upper contact with the Cross Brook Formation is also not exposed, it can be approximately defined where grey-green sandstone and shale of the Lochiel Formation give way to relatively coarse green lithic sandstone and minor conglomerate of the Cross Brook Formation, which, in contrast to the rocks of the Lochiel Formation, contain abundant clasts of Meguma terrane derivation.

\section{Age}

Three spore-bearing samples from the Lochiel Formation in the Denver region (Fig. 2b) give Tournaisian ages correlative with the low to lower middle portion of the Horton Bluff Formation in the Annapolis Valley (G. Dolby, personal com- munication, 1994). Benson (1974) reported minor plant remains in grey siltstone and black shale from locations in the Lochiel Formation and reported spores as old as those in the Horton Bluff Formation. He correlated the formation with the Cheverie Formation and considered it to be a "time-transgressive middle to upper Tournaisian formation". This is consistent with the results of the present study.

\section{Graham Hill Formation}

\section{Definition and lithologic description}

The Graham Hill Formation is variably exposed over a large area near Truro (Fig. 3). It is well-exposed on river sections in the vicinity of Graham Hill, on Lepper Brook in Victoria Park in Truro, and on Salmon River beneath the unconformable contact with the Triassic Wolfville Formation. A short section, $120 \mathrm{~m}$ thick, was measured in a red-weathering interval on the Pembroke River north of Graham Hill (Fig. 7b; location 4, Figs. 2b, 3). Murphy et al. (1995) included the formation as part of their map unit 5 .

The Graham Hill Formation typically consists of alternating, thick, red- and grey-weathering intervals of conglomerate to fine sandstone (Fig. 8a). At several outcrops, large channel scours occur, and in some instances the channel is filled with intraformational conglomerate. The sandstone is otherwise commonly trough cross-stratified (Fig. 8b), ripple cross-laminated and normally graded. Grey sandstone is, in places, interstratified with red, moderately-cleaved and locally-variegated red-green siltstone. Both finer-grained red sandstone and red siltstone in places display variegated redgreen mottling and bioturbation (root casts/burrows). Siltstone just above the contact with the Barrens Hills Formation contains desiccation cracks and carbonate nodules (Fig. 8c) interpreted as caliche development.

Grey, resistant-weathering intervals characteristically are on the order of several meters to several tens of meters thick and commonly fine-upward from very coarse-grained sandstone, granulestone, pebbly sandstone or quartz pebble conglomerate at the base to fine- to medium-grained sandstone at the top (Fig. 8d). Most fining-upward sequences consist mainly of erosionally amalgamated sandstone units that are decimeters in thickness. Basal conglomerates are polymict, framework-supported, and generally centimeters to several decimeters thick. They are either massive or contain scours and trough cross-stratification $(10-30 \mathrm{~cm})$. Clast types are rounded quartz (3-4 cm), subangular to angular dark grey, green, and red intraformational siltstone $(0.5-1 \mathrm{~cm})$, and rare, angular, red siliceous clasts $(0.5-1 \mathrm{~cm}$; probably of felsic volcanic origin). Sandstones contain little mica, are variably feldspathic (10$20 \%$ ) and slightly lithic with no discernible matrix. Some beds contain abundant comminuted plant debris. They are generally thin-bedded and contain abundant scour surfaces and trough cross-bedding in addition to ripple cross-lamination and parallel lamination. The sandstones at the top of the resistant intervals in many places retain evidence of erosional amalgamation; finer-grained tops are commonly transitional with overlying redbeds. 

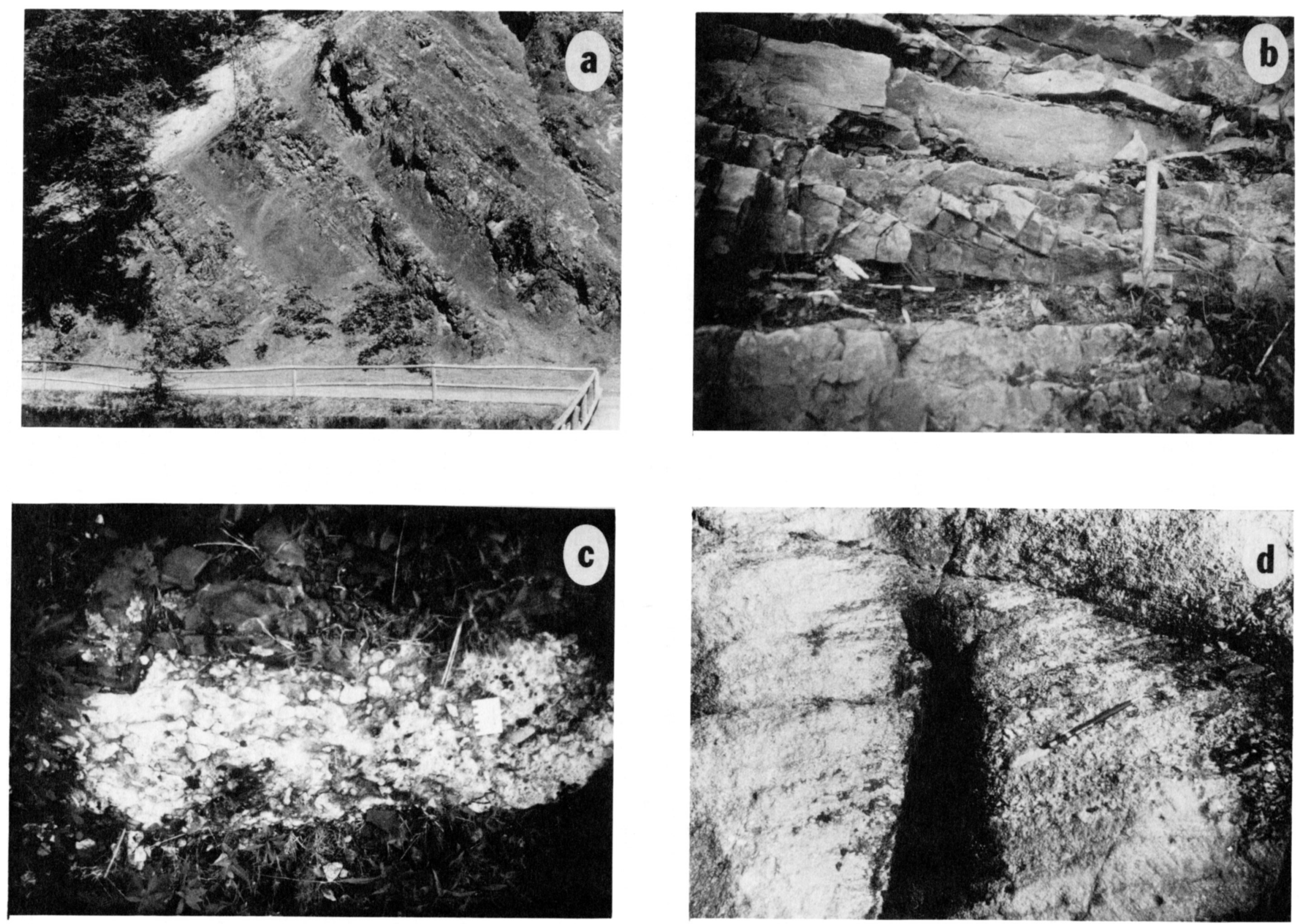

Fig. 8. Field photographs of lithologies of the Graham Hill Formation. (a) Red, fining-upward sandstone and siltstone sequences, Victoria Park, Truro. (b) Basal, large-scale trough cross-bedding in a resistant, grey, sandstone interval. (c) Thin bed of white, calcareous, poorly sorted, non-organized, matrix-supported, mudstone/siltstone clast conglomerate interstratified with red overbank siltstones, Salmon River. This type of bed was only observed once in the formation and is interpreted to constitute arid or semi-arid palaeosol. (d) Normally graded avalanche face foresets in polymict, granule to small pebble conglomerate containing minor (dark shade) volcanic clasts, Pembroke River. 
Recessive, red-weathering intervals in the Graham Hill Formation are generally thicker than underlying grey intervals. They are on the order of tens of meters to over $100 \mathrm{~m}$ thick and consist of interstratified sandstone gradually passing upward into siltstone with some shale. The sandstone is micaceous, feldspathic, and very fine- to medium-grained. The beds are typically thin (decimeter-scale), and very thin-bedded and contain abundant parallel laminations and ripple crosslaminations with less abundant larger cross-stratification (5$15 \mathrm{~cm}$ ). Thicker sequences contain evidence of erosional amalgamation. Rare examples of desiccation cracks, rain marks, and grazing traces occur in the very fine sandstone and siltstone. Indications of bioturbation (root casts and/or burrows) are common. One distinctive conglomerate bed, $40 \mathrm{~cm}$ thick, is thought to represent a palaeosol. The conglomerate weathers light grey to grey-white, is matrix-and clast-supported, and contains poorly organized, subangular, sedimentary clasts (grey, red, and green siltstone with minor red sandstone). The distinctive "pale" colour is attributed to a highly calcareous, light grey mudstone matrix. The silty shale/shaly siltstone at the top of the palaeosol is characteristically highly cleaved, thus generally obscuring primary features, although minor parallel laminations, ripple cross-laminations and root casts/ burrows are visible. Where exposed, the upper contact with the overlying grey interval is distinctly erosional. Other rare but distinctive lithologies include marl and dolomite, which occur on Salmon River (Fig. 3) where they are interlayered with compositionally mature sandstone.

Conglomerate beds occur at the base of several of the fining-upward sequences. The coarser conglomerate strata are grey-red weathering, polymict, and consist of granule to small cobbles that are predominantly framework to locally matrix supported. These strata are up to $1 \mathrm{~m}$ thick and have erosional bases. They contain large avalanche face foresets that are normally graded and display crude imbrication. Clast types include rounded quartz $(1-2 \mathrm{~cm})$ and subrounded siltstone and sandstone $(4-6 \mathrm{~cm})$, slate and schist $(0.5-1 \mathrm{~cm})$, and red felsic volcanic rock $(0.5 \mathrm{~cm}$, Fig. $8 \mathrm{~d})$. Other conglomerates display crude planar stratification and contain rounded quartz clasts up to $8 \mathrm{~cm}$ in diameter. On the Stewiacke River near Eastville (Figs. 2b, 3), interstratified sandstone and siltstone are dominant, with only minor, thin, granule to small pebble conglomerate beds.

\section{Stratigraphic position}

Based on plant ages from the Graham Hill and Greenfield Brook areas, Stevenson (1958) interpreted these rocks as a largely fault-bounded wedge "of Mississippian-age Canso Group sediment" extending southward to the Rutherford Brook (Fig. 3). However, spore ages obtained during this study (G. Dolby, written communications, 1993, 1994) indicate that these rocks are Tournaisian in age, agreeing with our mapping which indicates that they belong to the Horton Group. Benson (1974) assigned these rocks to the Ainslie Formation. However, they are lithologically distinct from rocks of the Lochiel Formation (see above) that were also assigned by Benson to the Ainslie Formation. Their occurrence stratigraphically above the Little
Stewiacke Formation suggests that they are laterally equivalent to the Barrens Hills Formation to the east. Like the Barrens Hills and Lochiel formations, the Graham Hill Formation occupies a stratigraphic position similar to the red-weathering Cheverie Formation (Bell, 1929) in the Avon River type area.

\section{Distribution, thickness and contact relations}

The Graham Hill Formation is exposed only on the Truro and western portion of the Hopewell mapsheets $(11 \mathrm{E} / 06$ and 11E/07) on several rivers between Truro and the Stewiacke River (including Salmon, Pembroke and Little rivers) and on road sections near Pembroke River east of Truro. The formation is relatively poorly exposed between two regional fold structures (Fig. 3).

Near Truro, the best exposures are invariably folded and locally faulted making thickness estimates difficult. However, we agree with the estimate of Stevenson (1958) of an approximate thickness of $4000 \mathrm{ft}$. $(1220 \mathrm{~m})$ for rocks herein assigned to the formation. On the Hopewell sheet, the formation pinches out approximately $14 \mathrm{~km}$ east of the Stewiacke River (Fig. 3). Benson (1967, map 1215A) proposed a thickness of approximately $1700 \mathrm{ft}$. (520 m) for rocks exposed along the Pembroke River assigned herein to the Graham Hill Formation. These thickness estimates suggest that the Graham Hill Formation thins significantly from west to east and are consistent with our mapping.

Regional contact relationships suggest that the Graham Hill Formation is a lateral facies equivalent of the Barrens Hills Formation. To the southwest of Truro, the formation overlies the Little Stewiacke River Formation, apparently conformably; the Barrens Hills Formation is absent (Fig. 3). To the east of Truro, detailed mapping indicates that the Graham Hill Formation is complexly interstratified with both the Barrens Hills and Little Stewiacke River formations. This observation, together with the interstratification of the Barrens Hills and Lochiel formations described above, indicate that these four formations are in part time equivalent. This interfingering is an example of the style of stratigraphic relationship thought to characterize the stratigraphic relationships among formations throughout the basin.

On the Pembroke River, the lower contact between the Graham Hill Formation and the Barrens Hills Formation, although not exposed, is interpreted to be conformable and transitional. This contact is faulted and only approximately constrained on the Stewiacke River.

To the south of Truro, an apparently concordant contact with the overlying Windsor Group is exposed. However, age data from the Graham Hill Formation (below) suggest a gap in the depositional record across this contact, indicating that it is a disconformity. Moreover, on a regional scale, the map pattern implies that the contact is probably moderately discordant. The contact with the Windsor Group is closely bracketed on Pembroke River (this detail cannot be resolved on Fig. 3; see Benson, 1967) and on a tributary of the Stewiacke River several kilometers north of Eastville (Stevenson, 1958, Murphy et al., 1994). There, the presence of a basal Windsor Group 
red pebble conglomerate is interpreted to indicate a disconformable contact.

Elsewhere the contact with the Windsor Group is apparently faulted. For example, a narrow east-west trending graben of Windsor Group rocks is in fault contact with the Graham Hill Formation to the north and south. To the south of the St. Marys Basin, a similar faulted relationship is reported along the flank of the Shubenacadie Basin (Stevenson, 1958).

\section{Age}

The maroon- to red-weathering lithologies of the Graham Hill Formation are too oxidized for preservation of spores. Grey-weathering lithologies, however, have yielded spore ages. Based on inconclusive spore determinations, Stevenson (1958) previously interpreted these rocks as Mississipian (Canso Group). However, Dolby (personal communication, 1994) reported that two samples collected during this study along Graham Hill indicate a "Horton/Albert (Tournaisian) Zone 3" age. This age is consistent with the Horton-age fragmentary plant fossil locality on Rutherford Brook reported by Stevenson (1958). The age determination together with lithostratigraphic evidence requires that the rocks assigned to the Canso Group by Stevenson (1958) should be re-assigned to the Graham Hill Formation. In addition, the spore data indicate that (a) the Graham Hill Formation on Graham Hill is slightly older than the westernmost West River St. Marys Formation (Cheverie equivalent; see below) on West River St. Marys, southeast Hopewell sheet, and (b) the formation is correlative with the upper part of the Horton Bluff Formation (G. Dolby, personal communication, 1994).

Benson (1967) reports fragmentary plant remains from grey beds from this area (location not specified) which Bell (1929) indicated were typical of the Horton Group.

\section{Cross Brook Formation}

\section{Definition and lithologic description}

The Cross Brook Formation consists of grey-green-weathering sandstone (Fig. 9a) interstratified with less abundant grey-green weathering siltstone, shale, conglomerate, and rare limestone. The formation can be distinguished from the Lochiel Formation by the abundance of igneous and metamorphic clasts (Fig. 9b) that are clearly derived from the Meguma terrane to the south. The formation is named after moderate exposures on Cross Brook, a tributary of West River St. Marys near the community of Caledonia (Fig. 2b). The formation also occurs to the east, although it is less well exposed.

Unfortunately, the lack of continuous exposure precludes the measuring of a stratigraphic section. Sandstone of the formation is typically fine- to coarse-grained, relatively micaceous and variably feldspathic, and locally contains varying amounts of granule-size quartz and sedimentary/metasedimentary lithic fragments. It is generally thinly bedded and commonly displays ripple cross-lamination, and trough cross-stratification in sets up to $1 \mathrm{~m}$ thick (Fig. 9c). Pebble conglomerates are polymict, poorly sorted, and framework supported. Dominant clast types in the sandstone and conglomerate include psammite, pelite, micaceous granite, vein quartz and muscovite. Less abundant, sedimentary clasts include laminated carbonaceous mudstone (possibly of algal origin), siltstone, sandstone, carbonate and organic debris, all of which are interpreted as intrabasinal detritus. Most clasts are subangular to subrounded. Siltstone and shale beds are grey-weathering, micaceous and display parallel lamination and ripple cross-lamination. A single massive $1 \mathrm{~m}$ thick limestone layer within a sandstone unit was found in the Cross Brook area.

\section{Stratigraphic position}

In Murphy et al. $(1994,1995)$ the Cross Brook Formation is referred to informally as map units 3 and $2 a$. It incorporates parts of Benson's (1974) Craignish and Ainslie formations in the region north of Cross Brook and in the area around West River St. Marys near the southern margin of the basin. The formation also includes unit 7a of Schiller (1961) and the Gunns Brook Formation of Mooney (1990) in the eastern part of the basin. The Gunns Brook Formation is abandoned because it can be subdivided into conglomerate- and sandstone-dominated sequences which correlate, respectively, with the West River St. Marys and Cross Brook formations to the west.

\section{Distribution, thickness and contact relationships}

The Cross Brook Formation underlies a large area extending approximately parallel, and north of the southern flank of the St. Marys Basin from Cross Brook in the west toward Salmon River Lake near Guysborough in the east (Fig. 2a, b). From there, the formation strikes northeasterly and is truncated by the Chedabucto Fault. Most of the best exposures occur near Cross Brook in the type area and along streams and logging roads near Highway 348 to the north of Cross Brook.

The formation thickens eastward and attains a thickness of ca. $1000 \mathrm{~m}$ (Murphy et al., 1994) in the type area. To the north, the Cross Brook Formation conformably overlies the Barrens Hills Formation. The contact is gradational over 500 $\mathrm{m}$ and is positioned where resistant quartzose feldspathic sandstone typical of the Barrens Hills Formation become less abundant than green sandstone and siltstone of the Cross Brook Formation. The northern contact with the Lochiel Formation (Fig. 2a) is not exposed but is interpreted to interfinger, as previously described. The upper contact with the West River St. Marys Formation is conformable and gradational, and is placed where poorly sorted conglomerates typical of the West River St. Marys Formation become dominant over sandstone typical of the Cross Brook Formation.

\section{Age}

None of the samples collected for palynological analysis provided an age for the Cross Brook Formation. Mooney (1990) reported that spores examined by J. Utting are typical of the "Vallasporites vallatus" assemblage (Utting et al., 1989), indicating a Tournaisian (Late TN2 to TN3) age. This age is 

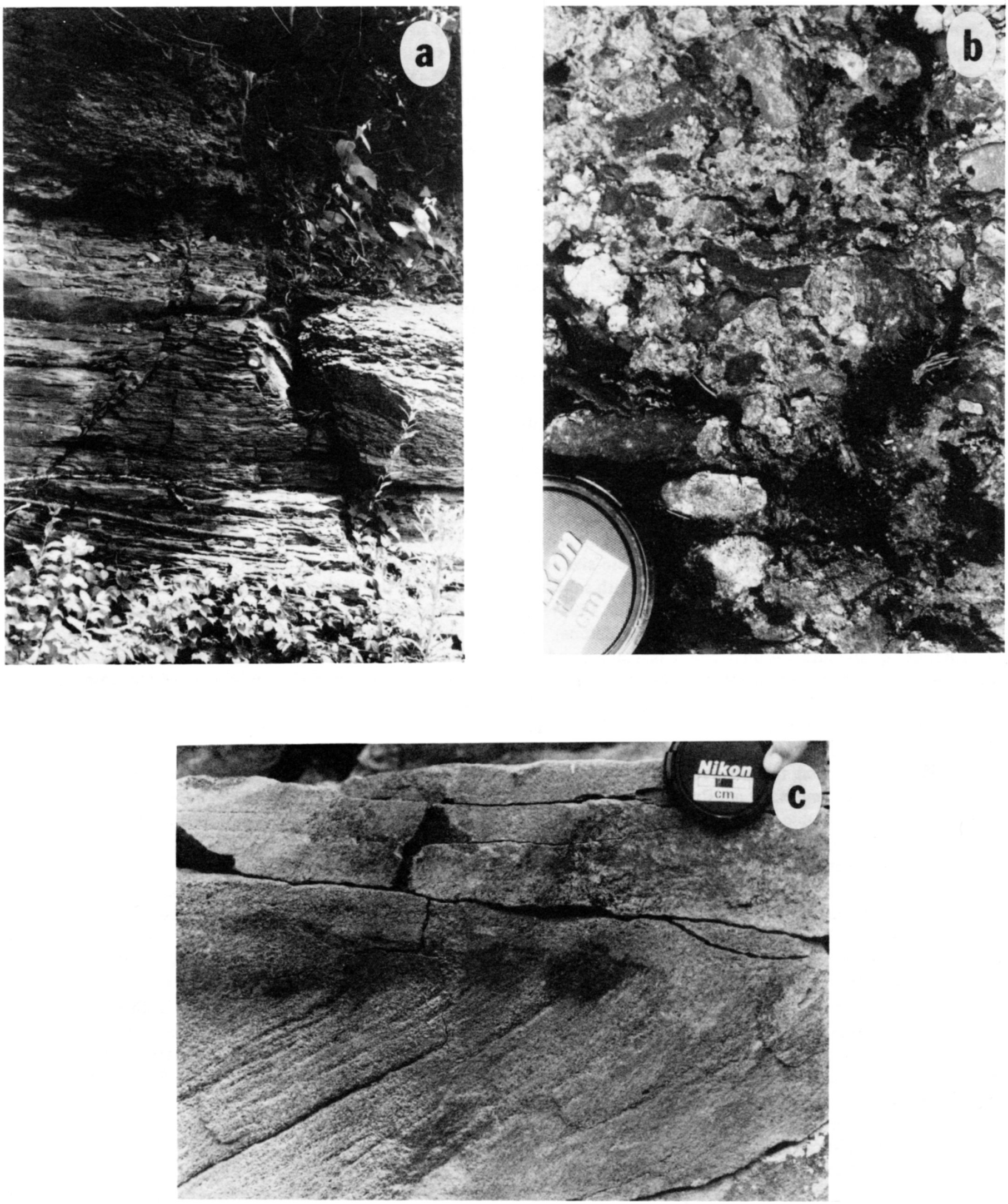

Fig. 9. Field photographs of the lithologies of the Cross Brook Formation. (a) Interstratified sandstone and granule to small pebble conglomerate sequence offset by steep normal fault, eastern St. Marys Basin. (b) Polymictic pebble conglomerate containing Meguma terrane (psammite, schist) and granitoid clasts, eastern St. Marys Basin. (c) Upper part of set of trough cross-stratification in grey, medium- to coarse-grained sandstone. 
similar to that obtained from the West River St. Marys Formation in the eastern part of the basin (see below) and is equivalent to a Late Zone 1 to Early Zone 2 of the Horton Bluff Formation (G. Dolby, personal communication, 1994).

\section{West River St. Marys Formation}

\section{Definition}

The West River St. Marys Formation consists of reddishbrown- to grey-green weathering conglomerate and interstratified sandstone. The formation outcrops along the southern flank of the basin (Fig. 2a), and is named after excellent exposures on West River St. Marys, approximately $3 \mathbf{~ k m}$ southeast of the community of Smithfield (Fig. 2b). In this region, a measured section at Rock Island Pool on West River St. Marys consists mainly of conglomerate (Fig. 7c).

The conglomerate contains clasts ranging from pebbles to boulders (Fig. 10a). The rock is dominantly framework- to locally matrix-supported with a roughly 80:20 framework to matrix ratio. It is very poorly to poorly sorted, and locally contains imbricated pockets, and displays crude inverse- to normal-grading. The conglomerate contains numerous major scour surfaces and fines upward to large pebble-size in the top of the measured section. Basal contacts with sandstone lenses are erosional. Point count studies (Mosher, 1994) indicate that the clasts consist of about $75 \%$ sandstone, $18 \%$ phyllite, $6 \%$ quartz and $1 \%$ quartzite. Clast shape and size varies with composition. Sedimentary clasts are largest (sandstone to $90 \mathrm{~cm}$, shale/siltstone to $6 \mathrm{~cm}$ ) and are subrounded to subangular. Metasedimentary clasts are similar in shape but generally smaller in size. Granite and quartz clasts are rounded to well-rounded, the latter reaching $30 \mathrm{~cm}$ in diameter (Fig. 9b). Sandstone clasts are fine- to medium-grained, micaceous, and feldspathic. In some places, they exhibit postdepositional en echelon tension fractures (Fig. 9c). Clast counts also indicate that metasedimentary clasts are marginally more abundant in the west and sedimentary clasts are more abundant in the east. Metasedimentary clasts are dominantly darkgrey-weathering pelite commonly with an inherited tectonic fabric. The matrix is grey-brown-weathering, medium- to very coarse-grained, feldspathic, lithic sandstone.

Conglomerate farther up-section is finer grained and better organized displaying imbrication and trough cross-stratification. In the eastern portion of the basin, these conglomerates contained a significant amount of plant debris (Fig. 10d) including fragments up to $30 \mathrm{~cm}$ long.

Sandstone occurs as trough-shaped lenses up to $2 \mathrm{~m}$ thick, but characteristically 30 to $80 \mathrm{~cm}$ thick, with a minimum lateral extent of $15 \mathrm{~m}$. The lenses weather grey-green and are medium- to very coarse-grained, feldspathic and micaceous. Rare interstratified pebbly or granulestone horizons occur. Scours, trough cross-stratification (sets to $30 \mathrm{~cm}$ ), ripple crossstratification and normal grading all occur in the sandstone. The number of sandstone lenses increases up-section.

In the eastern portion of the basin, Mosher (1994) identified quartz sandstone, phyllite, quartzite, and granitic pebbles and a variation in dominant clast type from quartz pebble lower in the section to sedimentary lithic dominant higher in the section. We noted grey and red intraformational shale clasts as well as minor coal and organic-rich shale fragments in the conglomerate. Schiller (1961) reported thin coal and carbonaceous shale seams in this region, which we were unable to locate.

\section{Stratigraphic position}

Murphy et al. (1994, 1995) and Mosher (1994) informally referred to the West River St. Marys Formation as map unit 4. It conformably overlies the Cross Brook Formation, and therefore represents the stratigraphically highest formation mapped in the basin.

\section{Distribution, thickness and contact relations}

The West River St. Marys Formation underlies a narrow zone along the southern margin of the St. Marys Basin on Lochaber and eastern Hopewell map sheets (11 E/08 and $11 \mathrm{E} /$ 09 ) and near Graham Hill Lake at the easternmost portion of the basin (Fig. 2a). The formation conformably overlies the Cross Brook Formation. The formations are intergradational over a stratigraphic interval of $500 \mathrm{~m}$. In the vicinity of Trafalgar (Fig. 2b), the West River St. Marys Formation is tentatively interpreted to be in contact with the Barrens Hills Formation, but the contact was not observed due to poor outcrop. It is also possible that the westernmost extension of the formation on the Hopewell sheet might interfinger with the Graham Hill Formation (described above).

Contact relationships with the Meguma terrane to the south vary from area to area. In the eastern portion of the basin, the formation is in faulted contact (West River St. Marys Fault) against metasedimentary rocks of the Meguma Group and Devonian granitoid rocks. In the central portion of the basin (e.g., near Caledonia, Fig. 2), the formation steps across the fault and lies unconformably on the Meguma terrane.

Although the West River St. Marys Formation overlies the Cross Brook Formation, they are considered partially laterally equivalent. They are defined as different formations because they can be mapped as separate units. However, they are probable laterally equivalent because spore evidence indicates overlap in depositional ages. Both are demonstrably derived from the Meguma terrane to the south, with the coarsergrained West River St. Marys Formation distributed along the basin margin, and the Cross Brook Formation immediately to the north.

\section{Age}

Spores were recovered from a sample obtained on a road section near Graham Hill Lake (Guysborough mapsheet). Dolby (personal communication, 1993) reported the age as Tournaisian and the zone as "TN 1 ?" suggesting "a possibly pre-Horton Bluff age equivalent" based on the presence of Spelaeotriletes crenulatus. Near the type area, Benson $(1974$, p. 82) obtained several productive samples along West River St. Marys which 

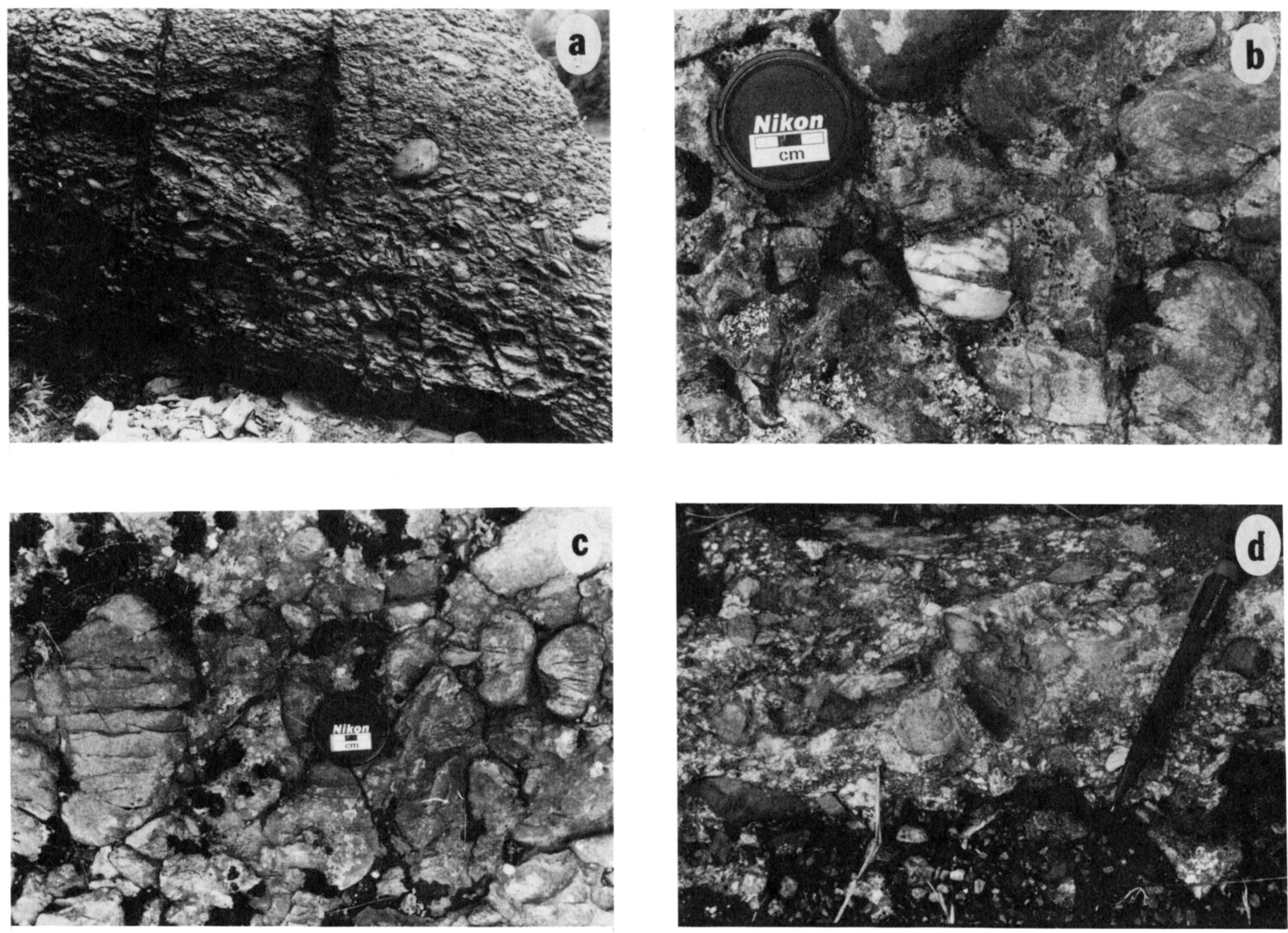

Fig. 10. Field photographs of the lithologies of the West River St. Marys Formation. (a) Small faults in poorly sorted and non-organized, polymictic, pebble and cobble conglomerate, at Rock Island Pool, West River St. Marys, near Smithfield, southern basin margin. (b) Meguma-derived, fractured vein quartz in polymictic pebble conglomerate, West River St. Marys. (c) Dilational fractures in Meguma-derived psammite clasts, conglomerate, West River St. Marys. The fractures post-date deposition and are sub-parallel to the southern basin margin. (d) Iron-stained, organic-rich beds in poorly sorted, quartz-pebble dominant, polymictic conglomerate at Salmon River Lake. The presence of organic debris suggests deposition by sporadic, short-lived, high energy, overbank flow events. 
gave ages ranging from possibly older than Horton Bluff to similar in age to the Cheverie Formation. Farther west, Benson (1967) reported spores equivalent to the Cheverie Formation of Bell (1929) from samples taken on the West St. Marys River approximately $1.5 \mathrm{~km}$ west of the mouth of Upper Bryden Brook. Taken together, these spore data suggest that the West River St. Marys Formation is a time-transgressive unit that youngs from east to west.

\section{Depositional environments}

\section{Little Stewiacke River Formation}

Stevenson (1958) proposed that rocks included here in the Little Stewiacke River Formation represent a lacustrine environment. We agree with this overall interpretation, and divide the formation into two members. We interpret the finergrained lower member of the Little Stewiacke River Formation to represent deeper water, below fair weather wave base deposition, and the coarser-grained upper member to represent an above fair weather wave base shoreface/strandline lacustrine sedimentary setting (see Hamblin, 1992). Comparable rocks are mapped as the Blue Beach Member of the Horton Bluff Formation in the Avon River type area (Martel, 1990; Martel and Gibling, 1996). Recent detailed studies of ostracode populations in the type area have revealed a periodic marine influence, suggesting a lagoonal/lacustrine environment (Tibert and Scott, 1995).

In the lower member, the organic-rich, and bioturbated nature of the finer sediment is compatible with a lacustrine setting. However, the setting is probably not as deep as other lacustrine settings in the Horton Group. For example, in the Albert Formation in New Brunswick, the lack of bioturbation is interpreted to be indicative of relatively deep anoxic conditions (St. Peter, 1993). Both fining-upward and coarsening(and sometimes thickening-) upward sequences probably represent relatively infrequent, waning-flow, micro-deltaic deposition (Hamblin, 1992). Minor grey to white, thin (centimeters), well sorted, compositionally mature sandstone beds in these sequences may represent redeposition of wave reworked sediment from the shoreface or beach environment. Indications of shallowing conditions exist in the less common coarsening- and/or thickening-upward sequences.

The sandstone-dominant character of the upper member and the interstratified thin quartz granulestone and minor small pebble conglomerate indicate a relatively higher energy environment. The member contains repetitive coarsening-up sequences (see Stewiacke River section, Fig. 4) that probably represent either an increase in the magnitude of the shoaling conditions of a lacustrine-deltaic environment. The occurrence of a grey siltstone, dolomite, and very compositionally mature white-weathering sandstone sequence on the Salmon River west of Riversdale is also interpreted as a shallowing lacustrine sequence finishing in a wave-worked strandline setting. The transitional relationships of the upper member with both the lacustrine lower member and the fluviatile Barrens Hills Formation, is consistent with this interpretation.

\section{Barrens Hills Formation}

The Barrens Hills Formation is interpreted to represent a gravelly to sandy braided fluvial environment. The predominance of quartz and feldspar clasts in the dominant sandstone lithologies suggests a granitic source.

The fining-upward sequences are proposed to represent the imperfect preservation of braid plain anabranch deposits through variably degradational lateral channel migration (e.g., Crowley, 1983). No stratigraphic trend in bed thickness was observed through a roughly $300 \mathrm{~m}$ section. In the type area, lithological arrangement of coarser-grained rocks and the greyto dark grey-weathering siltstone intervals up to several ten's of meters thick indicate a change in the depositional environment relative to the Stewiacke River location. The presence of thick, grey, fine-grained beds implies deposition below the water table and rapid removal from an oxidizing environment. These features are more likely to represent marginal lacustrine conditions such as a fan delta complex.

\section{Lochiel Formation}

The Lochiel Formation is interpreted to represent deposits of a lower gradient, sandy fluvial system (see Miall, 1995). Sandstone of the Lochiel Formation is distinguished from sandstone of the Barrens Hills Formation by greater compositional immaturity, grey-green weathering colour, and uncommon occurrence of conglomerate or pebby sandstone in interstratified sequences with grey siltstone and shale (Murphy et al., 1994).

The finer-grained nature of fining-upward cycles in this formation, the presence of planar cross-beds and the suspected lateral equivalence with the Barrens Hills Formation suggests deposition in transverse bars or more distal portions of a braided fluvial system.

The sandstone-dominant sequences are abundantly crossstratified, ripple cross-laminated and locally display channel scours and thicker amalgamated units. At the measured section on East River St. Marys (Fig. 7a), sandstone of the Lochiel Formation is erosionally amalgamated with sets of large scale trough cross-stratification up to roughly $60 \mathrm{~cm}$ thick.

\section{Graham Hill Formation}

The alternating grey and red siliciclastic rocks that dominate the Graham Hill Formation are interpreted as main channel (grey beds) and overbank (red beds) deposits of a single, high sinuosity, fluvial system (see Miall, 1995). The compositionally mature sandstone, marl and dolomite may represent upper shoreface to paralic deposition. The thick, red, finegrained thick sections with mudcracks, rainprints, calcrete and variegated palaeosols indicate dry to semi-dry flood plain conditions (Miall, 1996).

The occurrence of volcanic detritus in this formation, in contrast to the other formations, indicates the influence of the Avalon terrane as a source area. However, because the formation has a mixed provenance, typical Meguma detritus is also present. This observation is rare in Horton Group rocks 
in Nova Scotia and confirms the status of the Horton Group as a sequence that oversteps the Avalon-Meguma terrane boundary.

\section{Cross Brook Formation}

The Cross Brook Formation in the east St. Marys Basin shares many sedimentologic attributes with the Lochiel Formation and is similarly interpreted to represent deposition by a lower gradient, higher sinuosity fluvial regime (Miall, 1995). The presence of interstratified beds of moderately sorted polymict pebble conglomerate, however, indicates that this fluvial system also deposited coarser-grained detritus.

The presence of erosionally amalgamated sandstone intervals that are trough cross-stratified (up to $1 \mathrm{~m}$ thick) and fining-upward sequences consisting of coarse- to very coarsegrained pebbly sandstones or conglomerate at the base capped by siltstone is further indication of a high energy fluvial system. Excellent exposures of extensively trough cross-stratified and scoured channel sandstones along the southern flank of the basin (such as those immediately west of the bridge over West River St. Marys on Highway 348) support this interpretation and indicate a flow of considerable depth and by inference, also width. The interfingering nature of the northern contact of the Cross Brook Formation across the Lochaber sheet $(11 \mathrm{E} / 08)$ is interpreted as representing mixing of an axial (Barrens Hills, Lochiel) depositional system with the distal portion of an orthogonal alluvial fan.

Clasts in both the sandstone and conglomerate are typical of Meguma terrane lithologies, and are similar to those in the West River St. Marys Formation (described below). Taken together, the Cross Brook and West River St. Marys formations probably represent a northward-fining sequence of alluvial fan deposits associated with syn-depositional tectonic instability along the southern basin margin. The gentle dip of these units towards the basin marginal fault is consistent with syn-depositional subsidence along a northward-dipping listric normal fault.

\section{West River St. Marys Formation}

The West River St. Marys Formation along the southern margin of the basin (see measured section, Fig. 7) is interpreted as a high gradient, braided fluvial system possibly representing several, laterally coalescing alluvial fans depositing detritus typical of Meguma terrane lithologies.

The occurrence of boulder-size clasts at a number of 10calities along the southern basin margin strongly suggests that gravelly to sandy braided system(s) were operative on the surface of an alluvial fan(s). The varying character of the conglomerate (massive or stratified, matrix-supported or framework-supported, quartz-pebble dominant or sedimentary/ metasedimentary clast-dominant) suggests deposition principally as channellized stream flow with less common debris flows. The presence of organic debris in both the conglomerates and interstratified sandstones in the Salmon River Lake region and the abundance of mica in sandstones several kilometers east of Rock Island Pool, suggest that, at least at these locations, the character of the flows was short lived, high velocity, and gradually waning. Deposition of the interstratified sandstones and interbedded sandstones as continuous horizons or distinct channel-shaped lenses was by shallow channelized stream flows or sheet floods on the surface of, or distal to, alluvial fans. A shallow water depth is suggested by the paucity of larger scale cross-stratification.

The lack of organization and matrix-supported nature of some conglomerates of unit 4 suggest that debris flow deposition accompanied stream flow deposition on the alluvial fan(s) surface. Interstratified sandstone lenses likely represent reworking of the surface of the alluvial fan during high discharge events.

\section{Regional Horton Group stratigraphy} AND DEPOSITIONAL ENVIRONMENTS

Regional correlations have been proposed for the stratigraphy of the Horton Group in the Maritimes Basin from the Sackville and Moncton subbasins of New Brunswick (e.g., Martel, 1987; St. Peter, 1993) to the Deer Lake subbasin of northwestern Newfoundland (Hyde et al., 1988). The proposed correlations of Martel and Gibling (1996), including their interpretation of the St. Marys Basin, are shown in Figure 11.

Facies relationships along the southern flank of the St. Marys Basin clearly indicate that this boundary represents the original depositional margin of the basin. However, neither the character of Horton Group rocks, nor those of the other formations adjacent to the northern margin of the Basin show significant facies change with proximity to the Chedabucto Fault. Hence, this fault does not constitute the original basin margin and an unknown portion of the original basin has been tectonically removed by Late Carboniferous movement along the fault (Murphy et al., 1994, 1995). This interpretation suggests that correlatives of the basin-fill rocks may be found to the north of the Chedabucto Fault. In addition, reconnaissance examination of exposures of the Horton Group between Truro and the Windsor subbasin in the Annapolis Valley indicates potential stratigraphic continuity between these areas, implying that these sequences may belong to the same basin.

The depositional sequence in each of these subbasins (Fig. 11, after Martel and Gibling, 1996) typically consists of (i) a basal alluvial clastic succession which rests unconformably on basement rocks of various ages, overlain by (ii) a dark grey fine-grained lacustrine succession which contains midto-late Tournaisian (Tn2 to Tn3) spores (e.g., Utting, 1987; Utting and Hamblin, 1991; Martel et al., 1993; St. Peter, 1993), overlain conformably to unconformably by (iii) an upper coarseto fine-grained alluvial succession. Taken together, the deposition of the Horton Group spans latest Devonian (Fammenian) to Late Tournaisian (Tn3) times. However, these three successions are time transgressive and their times of deposition may overlap somewhat.

In the Avon River type area (Windsor subbasin) in the Annapolis Valley of Nova Scotia, the Horton Group is divided into a lower Horton Bluff Formation and an upper Cheverie Formation (Bell, 1929, 1960). Detailed mapping (e.g., Ferguson, 


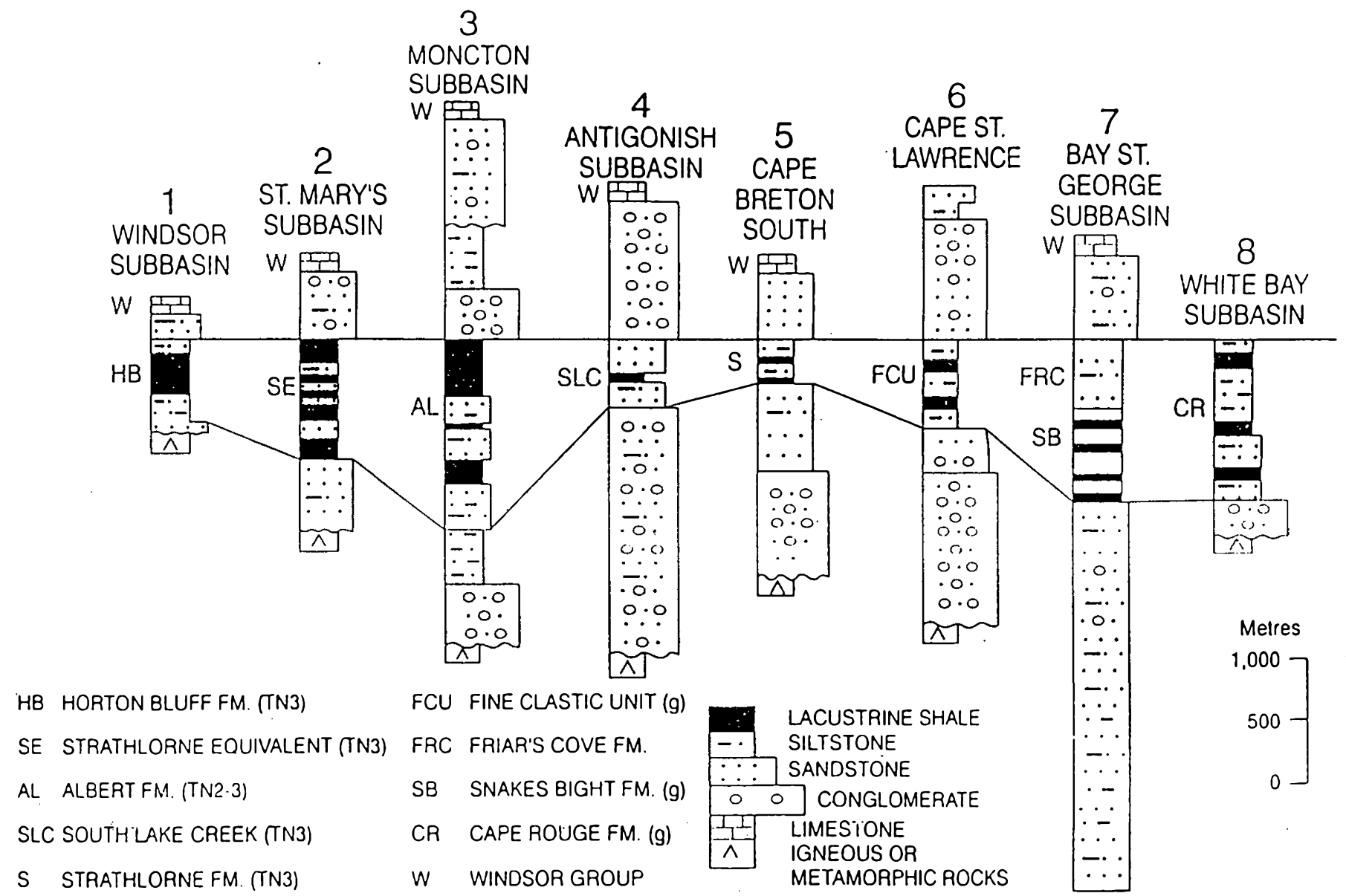

Fig. 11. Regional stratigraphy of the Horton Group in the Maritimes Basin (after Martel and Gibling, 1996). Stratigraphy of St. Marys Subbasin after Benson (1974).

1983; Moore and Ferguson, 1986), paleontological studies (e.g., Barss, 1967; Hacquebard, 1972; Martel et al., 1993) and sedimentological analysis (e.g., Martel, 1987, 1990) suggest a Late Devonian-Tournaisian age assignment for the Horton Bluff Formation and a late Tournaisian age for the Cheverie Formation.

The Horton Bluff Formation has been recently subdivided into members by Martel and Gibling (1996), (section 1, Fig. 11). The lowermost Harding Brook Member sits unconformably on Meguma basement and consists of ca. 100 $\mathrm{m}$ of sandstone with minor conglomerate, siltstone and mudstone deposited in a braided stream environment. The overlying Curry Brook Member is $120 \mathrm{~m}$ thick and consists of 1 to $4 \mathrm{~m}$ of coarsening-upward mudstone to sandstone cycles deposited in a coastal lacustrine to lagoonal environment overlain by the $210 \mathrm{~m}$ of the Blue Beach Member which is dominated by grey shales in coarsening-upward cycles. Martel and Gibling (1996) inferred that this member was deposited in a large wavedominated lake (ca. $50 \times 100 \mathrm{~km}$ ) and the recent identification of ostracodes typical of a lagoonal/lacustrine setting (Tibert and Scott, 1995) suggests that the proposed lacustrine environment was periodically connected to the sea. The overlying Hurd Creek Member is about $300 \mathrm{~m}$ thick and is dominated by coarsening-upward sandstone and clay-siltstone cycles. The sandstones are well sorted and many are commonly quart- zose and were interpreted as shoreline-attached sand bar deposits (Martel and Gibling, 1996). The overlying Cheverie Formation consists of ca. $100 \mathrm{~m}$ red coarse micaceous sandstones to siltstones thought to have been deposited in meandering streams.

Thus, in the typical three-fold division of Horton Group stratigraphy, the Harding Brook Member represents the basal alluvial sequence, and the Curry Brook and Blue Beach members indicate the development of lacustrine/lagoonal conditions. The Hurd Creek Member records the lake-margin conditions. The meandering stream environment of deposition of the Cheverie Formation is somewhat atypical of the Horton Group.

In Cape Breton Island, the Horton Group (see section 5, Fig. 11) follows a similar depositional sequence consisting of ca. 1500 to $2000 \mathrm{~m}$ of basal coarse-grained alluvial clastic sequence (Craignish Formation) overlain by 300 to $600 \mathrm{~m}$ of lacustrine grey mudstone and minor sandstone representing shoreline and fan delta/braidplain (Strathlorne Formation) followed by ca. $700 \mathrm{~m}$ of red to grey medium to coarse clastic alluvial sediments (Murray, 1955, 1960; Kelley, 1957; Hamblin and Rust, 1989).

In the St. Marys Basin, available fossil data confirm the predominant Tournaisian age of deposition. The interfingering nature of characterizing lithotypes of formations across for- 
mational boundaries implies some overlap in the ages of deposition of adjacent formations. The Little Stewiacke River Formation is the lowest stratigraphic unit exposed, and its lacustrine characteristics are similar to parts of the Curry Brook and Blue Beech members in the Avon River type area, and the Strathlorne Formation in Cape Breton Island. These lacustrine shales are generally correlated on the basis of similar spore assemblages ( $\operatorname{Tn} 2$ to $\operatorname{Tn} 3$, or mid to late Tournaisian of Utting, 1987). Although no definitive ages have been derived from the Little Stewiacke River Formation, it is overlain by the Barrens Hills and Cross Brook formations, the latter of which contains Tn2 to Tn3 spores (G. Dolby, personal communication, 1994). This provides an upper age limit for the Little Stewiacke River Formation that is consistent with the proposed correlations (Fig. 11). The upper member of the Little Stewiacke River Formation and the transitional section with the Barrens Hills Formation is analogous to the Blue Beach Member of the Horton Bluff Formation and the deltaic nearshore/ shoreline facies of the Strathlorne Formation.

These correlations also imply that the lowermost part of the Horton Group (equivalent to the Harding Brook Member of the Horton Bluff Formation or Craignish Formation) is not exposed in the St. Marys Basin, in contrast to the correlation scheme proposed by Martel and Gibling (1996), (see section 2, Fig. 11). A modified correlation of rocks of the St. Marys Basin with the Windsor subbasin and Cape Breton Island is shown in Figure 12.

The Barrens Hills Formation has no obvious correlative with either the Windsor subbasin or Cape Breton Island. It resembles some lithologies reported in the Hurd Creek Member, but its greater thickness and predominance of quartzofeldspathic mature sandstones distinguishes it from the Hurd Creek Member. The proposed depositional setting of braided streams for the Barrens Hills Formation is consistent with longitudinal drainage patterns (with respect to the subbasin axis) and sand bars between the lacustrine settings described above (see Fig. 13).

To the west, the Barrens Hills Formation interfingers with the Graham Hill Formation (Fig. 3) whose grey and redbed clastic lithologies are interpreted as channel and overbank deposits of a high sinuousity fluvial system. These lithologies are similar to the Cheverie Formation (Moore, 1985) in the Windsor subbasin and the central to basin-margin facies of the Ainslie Formation in Cape Breton Island (Hamblin and Rust, 1989). It should be noted that conglomerates representing the northern margin of the basin (such as those of the Ainslie Formation in Cape Breton), were not found in the study area.

To the east, the interfingering of the Barrens Hills Formation with relatively fine-grained micaceous lithologies of the Lochiel Formation and the inferred braided fluvial environment are indicative of variations of Horton Group basin centre facies, such as recorded in the Ainslie Formation of Cape Breton Island (Hamblin and Rust, 1989).

The location and clast composition of the Cross Brook and West River St. Marys formations along the southern flank of the St. Marys Basin suggest a basin-margin alluvial fan complex sourced from the Meguma terrane. Spore dates rang- ing from pre-Horton Bluff to Horton Bluff-Cheverie age suggest that deposition of the West River St. Marys Formation spanned nearly all of Horton Group time represented in the St. Marys Basin. Stratigraphic interfingering of the West River St. Marys and Cross Brook formations implies that the latter formation may have been deposited over a similar time interval.

Because the upper part of the West River St. Marys Formation may represent the highest Horton Group strata in the basin, it cannot be simply correlated with the Harding Brook basin-margin member of the Horton Bluff Formation in the Windsor subbasin. However, dated beds in both units indicate that their ages of deposition may have overlapped.

\section{Depositional model for the St. Marys Basin}

A depositional model for the fluvio-lacustrine deposits of the Horton Group in the St. Marys Basin is shown in two stages on Figure 13, and a schematic diagram showing potential depositional linkages with the Windsor subbasin and Cape Breton Island successions is shown in Figure 14. Each diagram shows the future location of the Late Carboniferous Chedabucto Fault to emphasize that only the southern portion of the St. Marys Basin is represented in the sections of Figures 11 and 12.

The model depicts the Little Stewiacke River, Barrens Hills and Lochiel formations to be predominantly related to longitudinal drainage in which a system of lakes (represented by the Little Stewiacke River Formation) are connected by a braided fluvial environment. The Barrens Hills and Lochiel formations were deposited as a fluvial system which migrated laterally across the floodplain.

The Graham Hill Formation shows the influence of drainage across the Avalonian margin to the north. Deposition of the Cross Brook and West River St. Marys formations are related to point sources and alluvial fan deposition derived from the Meguma flank to the south.

The Little Stewiacke River Formation was deposited in Tournaisian $\operatorname{Tn} 2$ to $\operatorname{Tn} 3$ as a lacustrine deposit representing a period of rapid subsidence and slow sedimentation along faults that bound the basin (Fig. 13a). The predominant southwardfacing direction of strata in the very mildly deformed eastern basin indicates more rapid subsidence in the southern portion of the basin. Basin margin facies represented by the Cross Brook and West River St. Marys formations (the latter of which has spores ranging from pre-Horton Bluff to Tournaisian Tn3) were respectively deposited as distal and proximal parts of an alluvial fan derived from erosion of the Meguma Terrane.

The Little Stewiacke River is one of a number of lacustrine depositional environments in the Maritimes Basin (Fig. 14) that were presumably separated by a basin-parallel drainage system whose deposits are represented in the St. Marys Basin by the Barrens Hills and Lochiel formations.

The end of the lacustrine phase of deposition is attributed to a decrease in the rate of subsidence and/or an increase in sediment supply that was greater than the creation of accommodation space. As a result, the fluviatile deposi- 


\section{St. Mary's Basin}

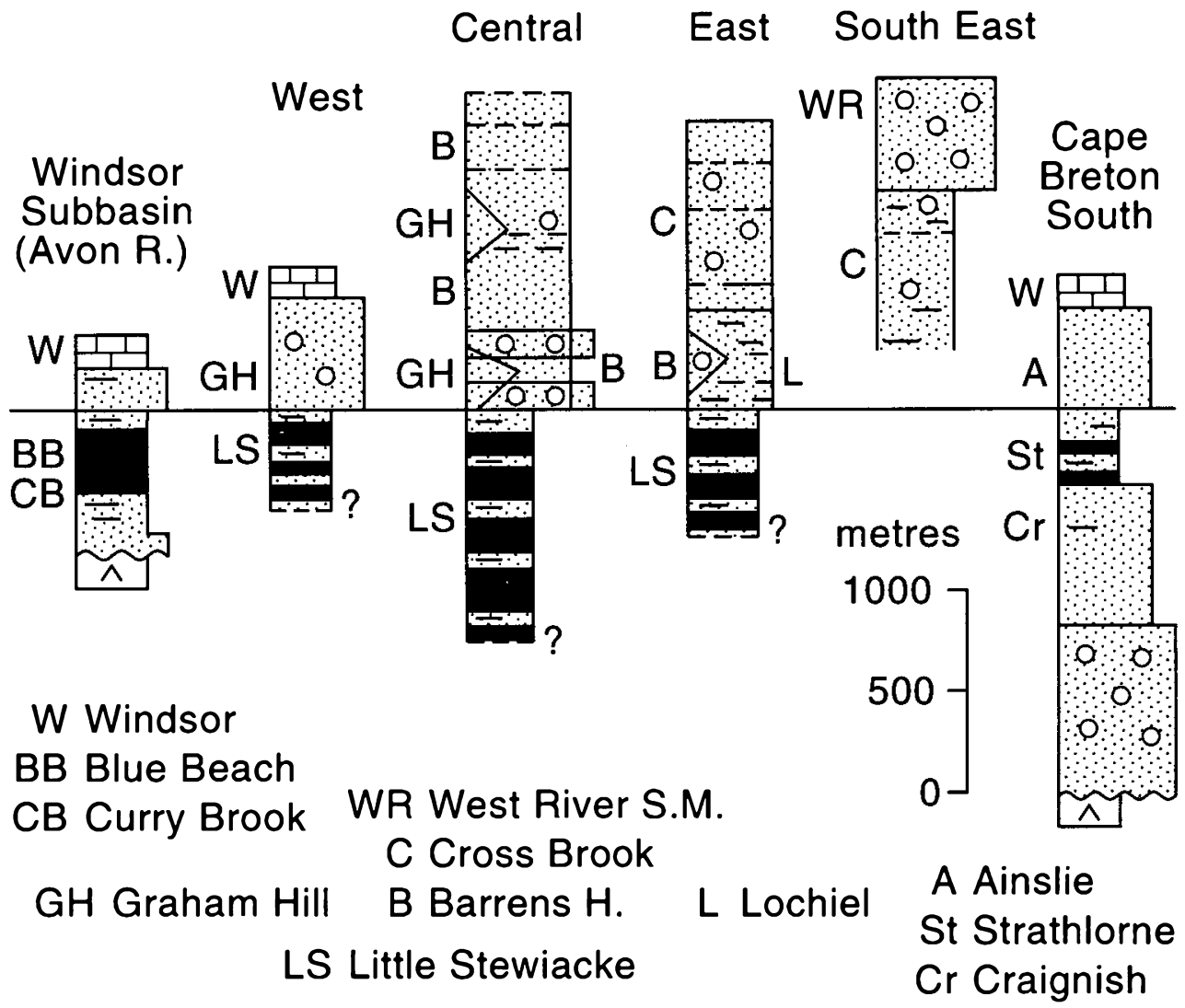

Fig. 12. Proposed stratigraphic correlation of Horton Group lithologies between the St. Marys Basin, the Windsor subbasin and southern Cape Breton Island. Rock-type symbols as in Figure 11.
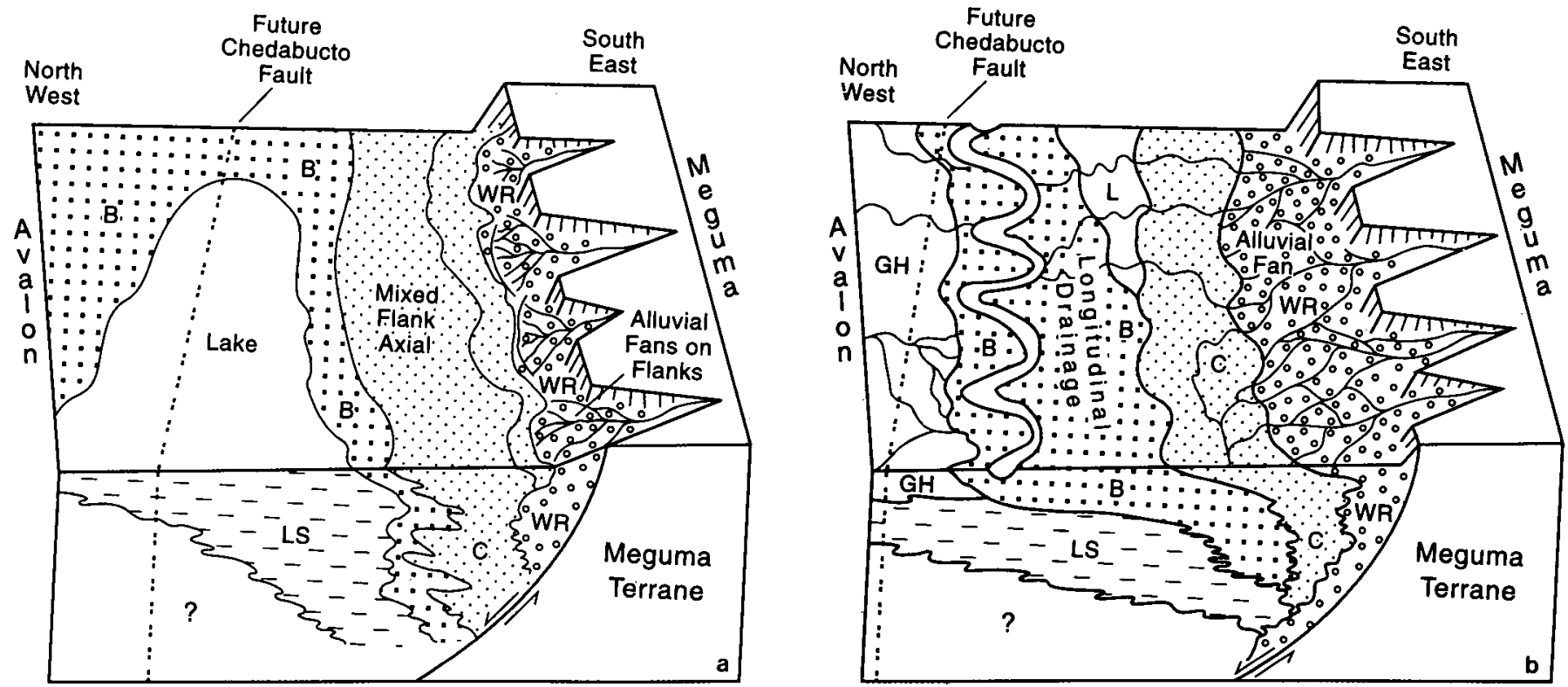

Fig. 13. Depositional environments (a) lacustrine stage of relatively rapid subsidence and slow sedimentation showing the deposition of the lacustrine Little Stewiacke River Formation (LS), the fluvial-shoreline Barrens Hills Formation (B) influenced by longitudinal drainage and the marginal facies of the West River St. Marys (WR) and Cross Brook (C) formations deposited respectively in the proximal and distal portions of alluvial fans sourced in the Meguma terrane to the south. (b) the progradation stage of slow subsidence, and relatively rapid sedimentation in which the Barrens Hills (B) and Lochiel $(L)$ formations represent the axial drainage system, the Graham Hill (GH) Formation represents a mixture of influences of axial drainage and the distal portion of an alluvial fan sourced in the Avalon Terrane; the Cross Brook and West River St. Marys formations are respectively deposited as the distal and proximal portions of prograding alluvial fans. 
AVALON TERRANE

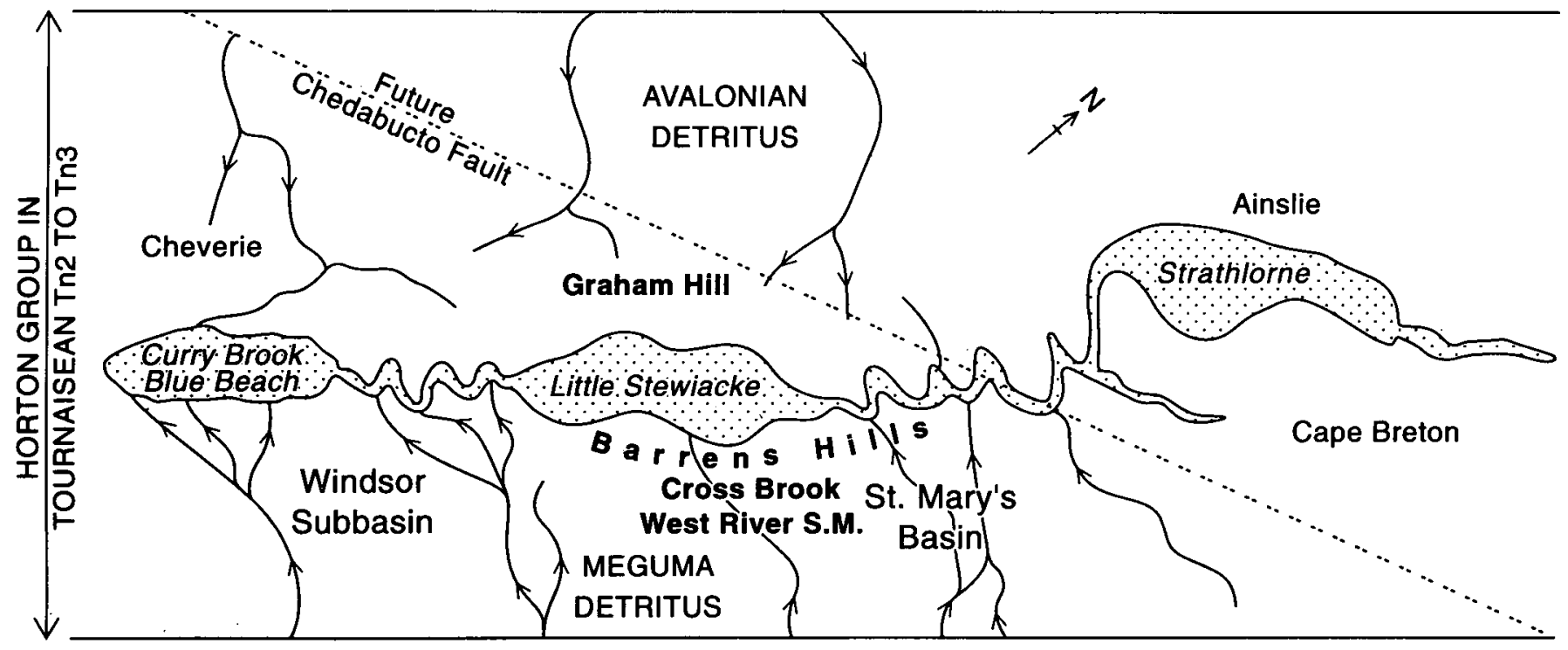

MEGUMA TERRANE

Fig. 14. Schematic representation of Horton Group paleogeography in Nova Scotia at the time of deposition of the lacustrine facies in the Windsor subbasin, St. Marys Basin and in southern Cape Breton Island.

tion represented by the Barrens Hills and Lochiel formations became more widespread. Continuing deposition of alluvial fan "point sources" from both flanks of the basin are represented by the West River St. Marys and Cross Brook formations to the south and the Graham Hill Formation to the west and north. The loss of accommodation space at this stage is indicated by the unconformable relationships between Meguma terrane lithologies and the West River St. Marys Formation with late Tournaisian fossils. These rocks are part of the stratigraphically highest formation in the basin, indicative that their deposition overstepped the basin margin.

\section{SUMMARY}

The east-west trending St. Marys Basin, central mainland Nova Scotia, occupies the boundary between the Meguma and Avalon terranes. The basin consists of a Late Devonian(?)Tournaisian intra-continental, fluviatile to lacustrine, basinfill sequence assigned to the Horton Group. Mapping has facilitated the definition of six new formations. Facies variations within the basin are interpreted in terms of axial (Little Stewiacke River, Barrens Hills and Lochiel formations) and basin-margin (Graham Hill, Cross Brook, West River St. Marys formations) depositional systems and the relative rates of tectonic subsidence and sedimentation. In general, deposition of coarse cobble conglomerates and lithic sandstones along a tectonically active southern basin margin represents point sources distributed in alluvial fans and proximal to distal fan-delta deposits. Longitudinal transport may be more dominant in central portion of the basin, which is characterized by lacustrine and axial fluvial systems associated with an early phase of rapid tectonic subsidence relative to sedi- mentation. In the later stages of basin evolution, however, lower relative subsidence rates resulted in less accommodation space and alluvial fans prograded from the Meguma and Avalonian flanks of the basin. As the basin-fill locally oversteps the West St. Marys Fault, at least a portion of the St. Marys Basin is underlain by rocks of the Meguma terrane. The conglomerates thicken markedly eastward along the southern margin, suggesting that the main sediment source lay to the southeast.

Although the Meguma terrane was the dominant sediment source, rocks with Avalonian detritus occur in the northwestern portion of the basin (Graham Hill Formation) confirming the status of the Horton Group as an overstep sequence with respect to the Avalon and Meguma terranes. Along the southern margin of the basin, the distribution of proximal and distal alluvial fan deposits and the unconformable relationships between Meguma terrane lithologies and Horton Group rocks indicate that this margin is representative of the original southern flank of the basin. In contrast, along the northern margin, sedimentary lithofacies do not change with proximity to the Chedabucto Fault, indicating that this fault does not constitute the depositional margin of the basin, implying that an unknown portion of the basin, and its basement, has been tectonically removed.

\section{ACKNOWLedgements}

We thank Fred Chandler for organizational support and continuous encouragement on behalf of the Canada-Nova Scotia Mineral Development Agreement, and Peter Giles and Greg Lynch on behalf of NATMAP, Graham Dolby for palynology (funded by NATMAP), Sandra Barr, Bob Boehner, Fred Chandler, Jun Cowan, Martin Gibling, Peter Giles, Lorne 
Jennex, Greg Lynch, Tony Hamblin, Tom Martel, Bob Ryan, Jacquie Stevens and John Waldron for informative discussions and Sandra Barr, Tom Martel and Clint St. Peter for very thorough and constructive reviews.

We would like to acknowledge our debt to previous workers in the area especially D. Benson, I. Stevenson, and E. Schiller. Their diligence and meticulous observations greatly facilitated our mapping, data collection and interpretations.

BARss, M.P. 1967. Illustrations of Canadian fossils: Carboniferous and Permian spores of Canada. Geological Survey of Canada, Paper 67-11, $94 \mathrm{p}$.

BeLl, W.A. 1929. Horton-Windsor district, Nova Scotia. Geological Survey of Canada Memoir 155.

-.--- 1960. Mississippian Horton Group of type Windsor-Horton district, Nova Scotia. Geological Survey of Canada, Memoir 314.

Benson, D.G. 1967. Geology of the Hopewell map area, Nova Scotia. Geological Survey of Canada, Memoir 343, 58 p.

-.---- 1974. Geology of the Antigonish Highlands, Nova Scotia. Geological Survey of Canada, Memoir 376, $92 \mathrm{p}$.

BradLey, D.C. 1982. Subsidence in Late Paleozoic basins in the northern Appalachians. Tectonics, 1, pp. 107-123.

CROWLEY, K.D. 1983. Large-scale bed configurations (macroforms), Platte River basin, Colorado and Nebraska: primary structures and formative processes. Geological Society of America Bulletin, 94, pp. 117-133.

DoNoHoE, H.V., JR. and WALLACE, P.I. 1982. Geological map of the Cobequid Highlands, Nova Scotia. Scale 1:50,000. Nova Scotia Department of Mines and Energy, Maps 82-6 to 82-9.

Ferguson, S.A. 1983. Geological map of the Hantsport area, Nova Scotia. Nova Scotia Department of Mines and Energy, Map 83-1, Scale 1:50,000.

Fletcher, H. and Faribault, E.R. 1887. Geological surveys and explorations in the counties of Guysborough, Antigonish, Pictou, Colchester and Halifax, Nova Scotia from 1882-1886. Geological Survey of Canada Annual Report, v. II, 1886, pt. P, pp. 5-128.

Hacquebard, P.A. 1972. The Carboniferous of eastern Canada. Septieme Congres Internationale de Stratigraphie et de Geologie de Carbonifiere, Krefeld, 1971, Compte Rendu, 1, pp. 69-90.

Hambin, A.P. 1992. Half-graben lacustrine sedimentary rocks of the lower Carboniferous Strathlorne Formation, Horton Group, Cape Breton Island, Nova Scotia, Canada. Sedimentology, 39, pp. 263-284

Hamblin, A.P. and Rust, B.R. 1989. Tectono-sedimentary analysis of alternate-polarity half-graben basin-fill successions: the Late Devonian-Early Carboniferous Horton Group, Cape Breton Island, Nova Scotia, Canada. Basin Research, 2, pp. 239-255.

HiLL, J.D. 1991. Petrology, tectonic setting and economic potential of Devonian peraluminous granitoid plutons in the Canso and Forest Hill areas, eastern Meguma Terrane, Nova Scotia. Geological Survey of Canada, Bulletin 383, $96 \mathrm{p}$

Hyde, R.S., Miller, H.G., HiscotT, R.N., and WRIGHT, J.A. 1988. Basin architecture and thermal maturation in the strike-slip Deer Lake Basin. Basin Research, 1, pp. 85-105.

KelLey, D.G. 1957. Baddeck map area, Nova Scotia. Geological Survey of Canada, Map 14-1956.

-1967. Some aspects of Carboniferous stratigraphy and depositional history in the Atlantic Provinces. In Collected Papers on Geology of the Atlantic Region. Edited by E.R.W. Neale and $\mathrm{H}$. Williams. Geological Association of Canada, Special Paper No. 4, pp. 213-228.
KEPPIE, J.D. 1982a. The Minas geofracture. In Major structural zones and faults of the northern Appalachians. Edited by P. St-Julien and J. Beland. Geological Association of Canada, Special Paper 24, pp. 263-280.

..... 1982b. Tectonic map of the province of Nova Scotia, scale 1:500,000. Department of Mines and Energy, Nova Scotia.

-.-.- 1985. The Appalachian collage. In The Appalachian Orogen - Scandinavia and related areas Edited by D.G. Gee and B.A. Stuart. John Wiley and Sons, Chichester, United Kingdom, pp. $422-437$

MarTel, A.T. 1987. Seismic stratigraphy and hydrocarbon potential of the strike-slip Sackville sub-basin, New Brunswick. In Sedimentary Basins and Basin-forming mechanisms. Edited by C. Beaumont, and A.J. Tankard. Canadian Society of Petroleum Geologists, Memoir 12 and Atlantic Geoscience Society, Special Publication 5, pp. 319-334.

- 1990. Stratigraphy, fluviolacustrine sedimentology and cyclicity of the Late Devonian/Early Carboniferous Horton Bluff Formation, Nova Scotia, Canada. Ph.D. thesis, Dalhousie University, Halifax, Nova Scotia, 297 p.

Martel, A.T. and Gibung, M.R. 1996. Stratigraphy and tectonic history of the Upper Devonian-Lower Carboniferous Horton Bluff Formation, Nova Scotia. Atlantic Geology, 32, pp. 1338.

Martel, A.T., MacGregor, D.C., and Utting, J. 1993. Stratigraphic significance of Upper Devonian and Lower Carboniferous miospores from the type area of the Horton Group, Nova Scotia. Canadian Journal of Earth Sciences, 30, pp. 1091-1098.

Mrall, A.D. 1995. Description and interpretation of fluvial deposits: a critical perspective: discussion. Sedimentology, 42, pp. 379-384.

-..- 1996. The Geology of Fluvial Deposits: sedimentary facies, basin analysis and petroleum geology. Springer, Berlin Heidelberg, $582 \mathrm{p}$.

MOoney, S.J. 1990. Stratigraphy of two late Paleozoic basins: implications for the timing of final emplacement of the Meguma terrane. M.Sc. thesis, Lakehead University, Thunder Bay, Ontario.

MooRE, R.G. 1985. Cheverie Formation. In Lexicon of Canadian Stratigraphy, v. VI, Atlantic Region. Edited by G.L. Williams, L.R. Fyffe, R.J. Wardle, S.P. Coleman-Sadd, and R.C. Boehner. Canadian Society of Petroleum Geologists, Calgary, pp. 7475.

Moore, R.G. and Ferguson, S.A. 1986. Geological map of the Windsor area, Nova Scotia. Nova Scotia Department of Mines and Energy, Map 86-2, Scale 1:50,000.

Mosher, S.J. 1994. Sedimentology of the southern St. Marys Basin, Nova Scotia. Unpublished B.Sc. honours thesis, St. Francis Xavier University, $42 \mathrm{p}$.

Murphy, J.B., Stokes, T.R., Meagher, C., and Mosher, S.J. 1994. The geology of the eastern St. Marys Basin. In Current Research 1994-D, Geological Survey of Canada, pp. 95-102.

Murphy, J.B., Rice, R.J., Stokes, T.R., and Keppie, D.F. 1995. The St. Marys Basin, central mainland Nova Scotia: Late Paleozoic basin formation and deformation along the Avalon-Meguma Terrane boundary, Canadian Appalachians. In New perspectives in the Cross Brookn-Appalachian orogen. Edited by J. Hibbard, C. van Staal, and P. Cawood. Geological Association of Canada, Special Paper 41, pp. 409-420.

MurRaY, B.C. 1955. Stratigraphy of the Horton Group in parts of Nova Scotia. Unpublished Ph.D. thesis, Massachuttetts Institute of Technology.

1960. Stratigraphy of the Horton Group in parts of Nova Scotia. Nova Scotia Research Foundation Publication. 
Schiller, E.A. 1961. Guysborough, Nova Scotia. Geological Survey of Canada, Map 27-1961.

-..- 1963. Mineralogy and geology of the Guysborough area, Nova Scotia, Canada. Ph.D. thesis, University of Utah, 162 p.

Stevenson, I.M. 1956. Shubenacadie, Nova Scotia. Geological Survey of Canada, Paper 55-27, map with marginal notes.

-... 1958. Truro map-area, Colchester and Hants Counties, Nova Scotia. Geological Survey of Canada, Memoir 297, 124 p.

St. Peter, C. 1993. Maritimes Basin evolution: key geologic and seismic evidence from the Moncton Subbasin of southern New Brunswick. Atlantic Geology, 29, pp. 233-270.

Tibert, N.E. and Scott, D.B. 1995. A paleoecological interpretation of the ostracodes from the lagoonal/lacustrine Late Devonian/Early Carboniferous Horton Bluff Formation, Nova Scotia, Canada. In Program with abstracts, $5^{\text {th }}$ International Conference on Paleooceanography, Halifax, Canada.

UtTing, J. 1987. Palynostratigraphic investigation of the Albert Formation (Lower Carboniferous) of New Brunswick, Canada. Palynology, 11, pp. 73-96.
Utting, J. and Hamblin, A.P. 1991. Thermal maturity of the Lower Carboniferous Horton Group, Nova Scotia. International Journal of Coal Geology, 19, pp. 439-456.

Utting, J., Keppie, J.D., and Giles, P.S. 1989. Palynology and stratigraphy of the Lower Carboniferous Horton Group, Nova Scotia. Contributions to Canadian Paleontology, Geological Survey of Canada Bulletin, 396, pp. 439-456.

Williams, H. 1978. Tectonic lithofacies map of the Appalachians: Memorial University map 1. Department of Geology, Memorial University of Newfoundland, St. Johns, Newfoundland, scale 1: 1,000,000.

---.- 1979. Appalachian orogen in Canada. Canadian Journal of Earth Sciences, 16, pp. 792-798. 